Federal Reserve Bank of New York

Staff Reports

\title{
Pandemics Change Cities: Municipal Spending and Voter Extremism in Germany, 1918-1933
}

Kristian Blickle

Staff Report No. 921

May 2020

Revised June 2020

Preliminary: Please do not cite without permission

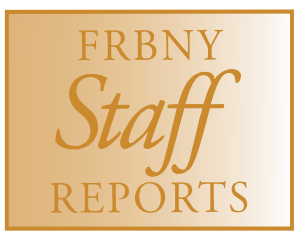

This paper presents preliminary findings and is being distributed to economists and other interested readers solely to stimulate discussion and elicit comments. The views expressed in this paper are those of the author and do not necessarily reflect the position of the Federal Reserve Bank of New York or the Federal Reserve System. Any errors or omissions are the responsibility of the author. 


\title{
Pandemics Change Cities: Municipal Spending and Voter Extremism in Germany, 1918-1933
}

Kristian Blickle

Federal Reserve Bank of New York Staff Reports, no. 921

May 2020; revised June 2020

JEL classification: H3, H4, I15, N14

\begin{abstract}
This paper uses several historical data-sets from Germany to show that influenza mortality in 1918-1920 was correlated with (i) lower per-capita spending, especially on services consumed by the young, in the following decade and (ii) the share of votes received by extremist parties in 1932 and 1933. These results are robust when controlling for demographics, population changes, city-level wages, city-level exposure to hyperinflation in 1923, and regional unemployment, and when instrumenting influenza mortality.
\end{abstract}

Key words: influenza, pandemic, municipal spending, voter extremism

Blickle: Federal Reserve Bank of New York (email: kristian.blickle@ny.frb.org). The author thanks Stephan Luck for guidance and Matthias Blum, Martin Brown, Nicola Cetorelli, Gregori Galofré-Vilà, Andrew Haughwout, Marvin Hier, Beverly Hirtle, Kilian Huber, Christopher Meissner, Felix von Meyerinck, Christian Ochsner, Maxim Pinkovskiy, Nic Schaub, Moritz Schularick, Johannes Stroebel, Nico Voigtlaender, Ekaterina Zhuravskaya for very helpful comments and suggestions. Any errors are the author's own. The views expressed in this paper are those of the authors and do not necessarily represent the position of the Federal Reserve Bank of New York, the Federal Reserve Bank of Dallas, or the Federal Reserve System.

To view the authors' disclosure statements, visit https://www.newyorkfed.org/research/staff_reports/sr921.html. 


\section{Introduction}

This paper investigates how the influenza outbreak of 1918-1920 affected German cities in the years after the pandemic. In particular, I analyze (i) city spending on amenities as well as (ii) voting for extremist parties in Germany between 1925 and 1933. A multitude of factors, many of which were specific to Germany in the 1920s, determined city spending and contributed to the rise in extremism. However, both per-capita spending and the vote share obtained by extremists varied significantly across municipalities. This variation represents tangible differences between individual cities that reflect the preferences or beliefs of inhabitants. Understanding the degree to which such preferences are correlated with major pandemics can offer insights to academics and policymakers alike. Germany represents a suitable case study for this analysis given that it suffered a high number of influenza deaths with significant regional variation, recorded detailed information on disease fatality, city expenditures, voting behaviour, etc., and experienced a well documented and researched increase in extremist voting in the 1920s and 1930s.

This paper documents several interesting and novel findings. First, areas which experienced a greater relative population decline due to the spread of influenza spend less, per-capita, on their inhabitants in the following decade. This holds especially for spending on amenities more likely to be consumed by the young, for example school funding. ${ }^{1}$ Second, influenza deaths of 1918 are correlated with an increase in the share of votes won by right-wing extremists, such as the National Socialist Workers Party (the Nazi Party), in the crucial elections of 1932 and 1933. This correlation holds even when controlling for a city's religious makeup, city wages, regional unemployment, city-level exposure to the "hyperinflation" of 1923, the share of right-wing votes before the first world war, and other local characteristics associated with extremist vote share. A one std. deviation increase in the proportion of the population killed by influenza was associated with an around $0.8 \%$-pt higher share of votes won by the national socialist party. The correlation between influenza mortality and vote share was negative for left-leaning parties also considered "extremist", such as the communists. ${ }^{2}$

While a number of confounding effects, some of which are discussed below, may drive these results, it is possible to at least rule out certain influences. For instance, there was no correlation between

\footnotetext{
${ }^{1}$ After all, the pandemic affected the young disproportionately in 1918 . However, this effect is likely compounded by the effects of the war, which affected a similar demographic.

${ }^{2}$ While the amount local governments spend on their inhabitants is correlated with the share of the vote won by extremist parties, as shown by Galofré-Vilà et al. (2019), this spending is not the driver of the observed correlation between mortality and extremist vote share found in this paper.
} 
fatality rates of other common diseases, and right wing extremist voting, especially when controlling for local healthcare provision. This implies that underlying access to medical services, which could reflect regional sophistication, was not driving the correlation between influenza mortality and extremist voting. Moreover, the correlation between voting and influenza mortality holds when instrumenting this mortality rate with the length and density of local railway lines in 1918. After all, when holding population density and local wealth constant, pandemics are more likely to spread in areas that are better connected. Instrumentation circumvents some endogeneity concerns that might result from other unobserved regional characteristics.

Ultimately, it is possible that changes in public sentiment, encouraged by anti-semitic and antiminority propaganda, drove the observed correlations between right-wing voting and influenza mortality. Following Voigtländer and Voth (2012a), I show that the link between influenza mortality and the vote share won by right-wing extremists was stronger in regions that had historically blamed minorities, particularly Jews, for medieval plagues. Following Adena et al. (2015) and their research on the importance of radio for propaganda, I show that the observed correlation between influenza mortality and right wing voting is compounded in areas with access to radio but only after the National Socialists began propaganda broadcasts over the radio. An increase in foreigner/minority hate has been shown by Cohn (2012) or Voigtländer and Voth (2012a) to occur during some severe plagues. Regions more affected by the pandemic may have gravitated towards political parties aligned with anti-minority sentiment. This may have been compounded by a pre-existing willingness of inhabitants to blame "others" and fueled by propaganda.

As pointed out above, the analyses discussed in this paper face a number of econometric challenges and the results must be interpreted with caution. Data on city spending, regional employment, historical pogroms, and disease mortality are all collected from various sources that do not map onto one another perfectly. Disease and employment data, for instance, are collected at the level of autonomous regions ${ }^{3}$. Often, a city was an individual administrative region. In some cases, however, an administrative region encompassed several towns. This means that, in some parts of the country, several cities will be assigned the same unemployment rates and disease fatality statistics. Secondly, data is not available at the same frequency or granularity throughout the sample period. This means the analyses discussed below are based on a relatively small sample of at most 75 cities per year. There seems to be no data on

\footnotetext{
${ }^{3}$ These were typically states, duchies, or kingdoms such as Bavaria, Baden, Oldenburg, etc. outside of Prussia and small administrative regions such as Berlin, Brandenburg, East-Prussia, etc. inside of Prussia
} 
city spending during the first world war or the hyperinflation period before 1925, which makes it difficult to control for certain city-differences. Finally, and perhaps most importantly, the end of the first world war brought several changes to Germany, which, combined with the war deaths themselves, reshaped populations. I attempt to account for war related population changes, but readily acknowledge that perfectly disentangling the effects of war and disease is difficult. It is possible that the observed correlations are the result of omitted variables, unrelated to the spread of the influenza pandemic. Nevertheless, the results are robust to a number of alternate specifications and possibly offer a novel contribution and foundation for a discussion on the effects of pandemics.

This paper contributes to a broad and rapidly growing literature. Firstly, it contributes to recent papers dealing with the effects of the spread of disease on various social and economic outcomes. Papers on such topics have grown in importance, as the effects of COVID-19 become more pronounced. Eichenbaum et al. (2020), for instance, show that less consumption (brought about by social distancing and forced store closures during the COVID pandemic) will reduce the severity of the pandemic, but may deepen subsequent recessions. Alfaro et al. (2020) show that changes in the progression and spread of the COVID-19 virus lead stock market returns. Bartik et al. (2020) survey small and medium sized enterprises. They document a significant heterogeneity in the degree to which firms are affected and in the beliefs of these SMEs about their own future and the aggregate economic recovery. ${ }^{4}$ Hamermesh (2020) shows that measures taken to combat the virus, such as social distancing, can affect people's mental health and attitudes. Bursztyny et al. (2020) show how important mass media can be by highlighting that exposure to misinformation can have long-term health consequences for the exposed.

Secondly, this paper contributes to literature that specifically analyzes the implications of the 1918 influenza pandemic. Barro et al. (2020), for instance, show that extrapolations of the effect of the 1918 pandemic could reveal an upper bound for the ultimate GDP effects of the current pandemic. Correira et al. (2020) use the 1918 pandemic to show that public safety interventions, such as lock-downs, can have long term economic benefits. They show that counties, which better combated the influenza pandemic, saw better economic recoveries. ${ }^{5}$ Brainerd and Siegler (2003) show that the 1918 epidemic had long lasting implications for the GDP of US states. However, they find a positive correlation between the

\footnotetext{
${ }^{4}$ Many studies deal with the spread of pandemics more directly. Markowitz et al. (2018) show that employment can be a vector for the spread of influenza. This may lead to an inverse correlation, in the data, between regional employment and the spread of influenza. In a similar vein, Kuchler et al. (2020) show that social networks can help propagate a shock. Regions with denser social networks and more direct links to outbreak hotspots may be more affected. Atkeson (2020) also models the spread of viral infections through a society and highlights the importance of contacts.

${ }^{5}$ Markel et al. (2007) also study (and find favorable results for) the efficacy of nonpharmaceutical interventions.
} 
severity of the epidemic and subsequent economic growth. Almond (2006) and Guimbeau et al. (2020) both show that the pandemic had long term implications on the development of people, especially those born/in-utero during the pandemic. Both MacKellar (2007) and Garrett (2008) provide good overviews of the influenza pandemic, and many of its consequences, for the US context.

Finally, this work ties to an older, though ever-growing, body of research that analyzes the gains made by the extremists, first and foremost the National Socialist party, in the elections of 1932 and 1933. The causes for the gains made by the National Socialists between 1928, when they took just over $2 \%$ of the vote, and 1933, when they cemented their hold on power, have been much debated (see for instance Eichengreen (2018), Ferguson (1996), Ferguson (1997), Hoffmann (1965), James (1986), Straumann (2019), Temin (1971), and Temin (1990) for a few views). Many of the primary causes are likely to have been economic in nature, related to unemployment, inflation, and large expenditure cuts (see Galofré-Vilà et al. (2019) for an excellent overview ${ }^{6}$ ). However, many additional factors may have contributed in some way to the party's rise. Geary (2002) summarizes some of the literature on the extremist right-wing successes in capturing working class votes. Voigtländer and Voth (2012a) and Voigtländer and Voth (2012b) highlight the importance of antisemitism in driving extremist voters. Importantly, they show how persistent certain sentiments, especially those pertaining to hatred of "others" (such as antisemitism), can be. In many regions the sentiments lasted hundreds of years. Satyanath et al. (2017) show that the rise of fascism was correlated with the city-level density of associations. Ferguson and Voth (2008) show the importance of links between the National Socialist party and the largest industrial firms ${ }^{7}$. Adena et al. (2015) show that propaganda helped fuel the rise of the National Socialist party. Importantly, they highlight that areas with pre-existing antisemitism were more susceptible to racist propaganda.

This paper contributes to the above research by showing that pandemics affect the provision of public goods and may be correlated with extremist voting; an effect that may be exacerbated by pre-existing anti-minority sentiments, or disease-focused propaganda.

\footnotetext{
${ }^{6}$ Doerr et al. (2020) explore how bank failures may have exacerbated extremist voting while Huber et al. (2019) show that rises in anti-semitism caused the widespread dismissal of Jewish managers, which in turn resulted in lower performance at affected firms.

${ }^{7}$ Similar arguments are made by Voigtlaender and Voth (2014) when analyzing the economic competence displayed by the National Socialist party during its rise.
} 


\section{Data and Methodology}

\subsection{Data}

This section gives a brief overview of the sources of data used for the analyses below. Additional information on the data sources can be found in the appendix.

Data on influenza deaths is taken from the Statistisches Jahrbuch fuer das Deutsche Reich (German: Annual Statistics for the German Reich). For each of the major administrative regions of Prussia as well as the remaining German states the book lists various causes for mortality, including: childbirth, cancer, heart disease, violence, tuberculosis, communicable diseases, accidents, and importantly, influenza for several years, including 1918-1920. 1918 saw the largest spike in influenza deaths, while 1919 and 1920 saw smaller, though sizeable, recurrences of the disease. In total, Germany experienced about 174,000 influenza deaths in 1918 and another approximately 42,000 and 57,000 in 1919 and 1920, respectively. The data is recorded separately for men and women, allowing for an additional level of granularity. The influenza mortality rate is calculated by dividing the total number of confirmed influenza deaths in a region by the total population of that region.

[Figure 1 about here]

Figure 1 depicts the total number of civilian influenza deaths as well as the total number of civilian deaths from disease and violence per year. A spike in mortality is clearly visible in 1918. Influenza mortality drove up aggregate mortality, which had been trending down even during the war years, by almost $20 \%$. These figures do not include the population serving in the armed forces and do not include war-related deaths. Unfortunately, data collection methodology changed after 1922 to reflect hospitalization due to disease rather than mortality. By 1924, hospitalization due to influenza had fallen to around 20,000 people, reflecting a return of almost pre-outbreak influenza mortality. Importantly, influenza deaths were not distributed evenly throughout Germany. Influenza mortality in German regions in 1918 ranged from $0.15 \%$ to $0.35 \%$. These figures reflect the share of a local population that died because of an influenza infection in a given year. These rates are lower than the disease-mortality itself, given that not every inhabitant contracted influenza. An overview of the geographic variation in influenza mortality can be found in the appendix. ${ }^{8}$

\footnotetext{
${ }^{8}$ The appendix also touches on the fact that disentangling influenza mortality from certain other diseases may have been difficult in some cases. Even doctors may have had difficulty fully distinguishing pneumonia from influenza. One can observe a small, though less pronounced, increase in pneumonia related fatalities in 1918. This paper makes use of cases defined by
} 
Unfortunately, as indicated above, the data on influenza deaths is only available at a regional level. I assign each city, for which I have data, to a region and assume that the city experiences the same mortality rate as the entire region. For purposes of this paper, there were around 25 distinct regions that reported mortality data in Germany in 1918. These regions reflect the complicated geographical makeup of the country at the time. The term region is used broadly to mean independent zones that include states, independent cities, and administrative areas within the large state of Prussia. Some regions are individual cities, such as Berlin, Hamburg or Bremen; in these cases, a mapping of city data and region data is simple. Other regions are geographically very small, no larger than modern US counties, and contain only one town or city of note, such as Braunschweig, Anhalt, or Oldenburg. Here, a mapping of city to region is, again, relatively simple. Other regions, however, are either geographically large, such as Bavaria, or densely populated, such as Westfalen. Bavaria, in particular, is around twice the size of the next largest region and contains several distinct cities. Westfalen, on the other hand, is much smaller but densely populated. For densely populated regions the assumption of homogeneous mortality rates is defensible. This assumption might prove less true in larger, rural, states like Bavaria. The robustness section, below, highlights the fact that the results are not driven solely by mortality in any one region and are robust to the omission of individual states.

Unemployment data is obtained from the same source as mortality data. Given changes in how unemployment was recorded, the most accurate information comes from 1930 and $1931 .{ }^{9}$ Baseline specifications make use of data for 1930 and 1932. Unfortunately, unemployment data poses an additional challenge as it is somewhat less granular than mortality data. Independent cities are subsumed into the unemployment statistics of the nearest state. I map unemployment information to the regions and assume that all cities in a region observe the same unemployment rate. This assumption is, again, defensible in small regions if one assumes that people could attempt to commute some distance to a job. An alternate definition of local employment and labor market conditions may be gleaned by looking at city-level wages. Wages for various professions are recorded at the level of the city. Wages may reflect labor market conditions more broadly as they capture underemployed or underpaid workers in the lead-up to more extremist voting. Wages also reflect the deflationary pressures exerted on the economy

the historical records as influenza, though it is likely that reported influenza deaths may constitute a lower-bound of total influenza deaths. It is possible that the accuracy of classifying influenza deaths as "influenza" instead of pneumonia, may have correlated with the sophistication of medical facilities in a region. The Appendix therefore also deals with specifications that lump both influenza and pneumonia deaths together.

${ }^{9}$ Prior to 1930, only the number of distinct job applications with the local employment office was recorded. It is possible that some individuals applied for multiple jobs while others applied for none. 
at the time $\mathrm{e}^{10}$. I obtain city-level wages on a variety of industries for a number of years from labor statistics published at the time. Baseline specifications make use of the average wages for metallurgy workers in a city in a given year.

Data on the expenditures of individual cities comes from the Statistisches Jahrbuch Deutscher Staedte (German: Annual statistics of German cities). These are a series of books, published annually, that record various statistics for German towns with a population of more than 100,000 inhabitants. These books are obtained from the German national archives in Berlin. The data in these books includes details on city spending on the police force, fire brigade, street and building maintenance, utilities, general administration, cultural institutions (such as theaters or museums), as well as amenities such as parks and swimming pools. The books are published with a lag of between one and two years and do not exist for every consecutive year. Data on spending exists for the years 1925, 1927, 1928, 1930, 1931, and 1932/33 ${ }^{11}$. The amount a city spent on various amenities was not merely a function of taxes it collected. The period after the end of hyperinflation and before the start of the great depression in Germany was marked by cheap credit, partly spurred by foreign investment, and an increase in borrowing. The spending of certain cities grew to the point that the treasury minister of Germany at the time admonished cities for frivolous spending (Born, 1967). An excellent discussion of the budget constraints faced by cities can be found in Galofré-Vilà et al. (2019).

Data on pogroms is taken from Voigtländer and Voth (2012a) as well as indirectly from Haverkamp (2002). I define cities as having had a "severe" pogrom if they killed, expelled, or disowned their Jewish population around 1350. Pogroms were particularly common in the Rheinland area as well as in Bavaria. Interestingly, the Rheinland, overall, saw a smaller share of votes go to the National Socialist party during the elections of 1932/33. Data on radio use in various municipalities is taken from Adena et al. (2015).

Data on hyperinflation comes from the monthly bulletin "economy and statistics" Wirtschaft und Statistik which was issued by the statistical office of the Reich. It includes monthly inflation data (German: teuerungsraten) for 72 cities. Unfortunately, the overlap of cities in the inflation data and the larger data set is - once again - not perfect. If an exact match is not possible, inflation for the nearest city, geographically, is used. This occurs most frequently for the Ruhr area of Westfalia and regions in Upper Silesia. At least in the case of the Ruhr, the assumption that many cities experience the same

\footnotetext{
${ }^{10} \mathrm{~A}$ brief historical overview can be found in the Online Appendix

${ }^{11}$ It appears that the final year may contain some mixed data over two years for some cities.
} 
inflation rate is defensible, given their proximity and joint occupation by the French and Belgian troops during the first half of the 1920s.

Data on voting behaviour comes from ICPSR data on German elections. Particularly the elections of 1932 and 1933 saw a stark increase in the share of the vote won by extremist (primarily right-wing extremist) parties. I map the election data onto cities by name; for some cities, election data is more granular than the city itself (such as Berlin). In these cases individual election zones are aggregated to the city level. ICPSR data contains a few additional demographic details, such as the share of a local population that was Jewish or Catholic, during the most recent census of 1925.

\section{[TABLE 1 ABOUT HERE]}

Table 1 shows summary statistics for some key variables. Unless otherwise specified, the reference year is 1931. In 1931, a full set of data is observable for 72 cities, for most, but not all key variables. While this is a relatively small sample, one can nevertheless observe significant heterogeneity across cities in terms of the variables of interest. Influenza mortality ranges from $0.15 \%$ of the population to $0.388 \%$ of the population. City spending per inhabitant ranges from 93 Reichsmark to over 244 Reichsmark. While the data includes total city expenditures per inhabitant, it does not always include details for each sub-category in every city. Nevertheless, for cities that do report data, spending on schools ranges from less than 4 Reichsmark to more than 37 Reichsmark per person and spending on cultural amenities ranges from practically zero to over 26 Reichsmark per person. These figures vary somewhat over time. As a consequence, one can also observe a significant heterogeneity in the contraction of spending per inhabitant between 1930 and 1933, with the average city shrinking its expenditures by almost 13\%, while select cities continue to grow their spending. ${ }^{12}$ There is further significant heterogeneity across town size as well as in the growth rate of towns and regions. City-level inflation rates range from around 100,000 percent to 180,000 percent at their extreme. Occupied regions in the Ruhr valley experienced particularly severe inflation (see online Appendix for a historical discussion). Finally, unemployment shares are calculated relative to the entire population (as opposed to the working age population).

\footnotetext{
${ }^{12}$ There are some changes in how city-level populations were recorded between 1912 and 1930. Given that this did not appear systematic, the change in city-level population is included as a control.
} 


\subsection{Methodology}

In a first step, I attempt to measure the relationship between the share of the population killed by influenza in 1918 (or between 1918 and 1920) and city expenditures in the years between 1925 and 1932. Such a relationship may exist because influenza (i) affected young people disproportionately ${ }^{13}$ (ii) may have changed societal preferences going forward. Naturally, the economic and societal turmoil that followed the end of the war, particularly in Germany, add additional complications for which controlling can be difficult. I attempt to hold constant as many confounding influences as possible, and so regressions take the following form:

$$
\text { Spending }_{c, r, t}=\beta_{0}+\beta_{l} \text { InfluenzaMortality }_{r, 1918}+\mathbf{X}_{c}+\theta_{t}+\xi_{r}+\epsilon_{c, t},
$$

Spending ${ }_{c, r, t}$ captures the spending per inhabitant of city $c$ in region $r$ at time $t$. I make use of aggregate spending in the baseline regression but differentiate out various sub-categories, such as spending on schools, fire-brigades, culture, or amenities as well. The coefficient of interest is $\beta_{l}$, which measures the relationship between spending per inhabitant and the share of the population that died from influenza in region $r . \mathbf{X}_{c}$ are additional city characteristics. These include, for instance, the share of the city that is Jewish or Catholic in the year 1925, the size of the city, population changes in the city between 1912 and 1918, city wages in 1930 and changes in wages between 1930 and 1932. The regressions additionally include data on the highest level of inflation experienced by the cities in 1923, relative to a baseline of prices in 1913/14. There existed some city level variation in inflation, which, given the pronounced psychological effect inflation had, may have affected city preferences in the following years. The equations further include fixed effects for the "city-tier group". Germany classified its cities into three broad and five narrower tiers based on size and level of development. These fixed effects therefore absorb important differences between types of cities. $\theta_{t}$ are year fixed effects while $\xi_{r}$ are region controls, such as unemployment in 1930 or 1931, the share of female influenza deaths, and regional population changes between 1910 and 1918 as well as city-level population changes between 1912 and 1930.

Spending are one form by which a city's priorities can be measured. Perhaps a more direct measure is voting behaviour. The main analysis of this paper relates the regional mortality rate of influenza in 1918 or (1918-20) to the share of votes obtained by extremist parties in 1932-33. As above, the regression

\footnotetext{
${ }^{13}$ Influenza mortality is often described as a "W", with mortality rate spikes among the very young, the very old, as well as those around 20-25 years of age. The absence of one cohort from the population and the shock caused by their demise may affect priorities of cities, and of their constituent voting households, going forward. Naturally, the first world war significantly confounds this analysis as it affected the same demographic.
} 
takes the following form:

$$
\text { ExtremistVote }_{c, r, t}=\beta_{0}+\beta_{l} \text { InfluenzaMortality }_{r, 1918}+\beta_{2} \text { CitySpending }_{c, t-1}+\mathbf{X}_{c}+\theta_{t}+\xi_{r}+\epsilon_{c, t} \text {, }
$$

ExtremistVote $_{c, r, t}$ relates the share of the vote won by extremists, in elections of 1932, 1933 or both elections combined. Nationalist-, National Socialists-, and communist-parties are considered extremist parties. In the primary analyses below, the focus is on the National Socialists, given their catastrophic rise to power in this period. The controls are the same as those discussed in Section 2.2 above. The regression additionally includes city-level information on per-capita municipal spending. This follows from the fact that unemployment, inflation, and austerity are known to correlate with voting for extremist parties. This follows from work by Galofré-Vilà et al. (2019) and explored in the online appendix. The coefficient of interest is $\beta_{l}$, which represents the correlation between the share of a population that died due to influenza in 1918 and extremist voting nearly 14 years later.

There are many channels through which influenza mortality may have abetted National Socialist gains. One possible channel, explored here, relates to changes in attitude based on pre-existing notions and abetted by propaganda. The National Socialists, in particular, related disease to certain ethnic groups, particularly the Jewish people (see Appendix for a brief overview). It is possible that areas with high levels of pre-existing anti-semitism were more receptive to such propaganda (consider Adena et al. (2015)). This may have been compounded in regions which were particularly affected by the pandemic. National Socialist propaganda is discussed briefly in the online appendix and the channel is explored below.

Given that key variation in the variable of interest originates at the region level, heteroscedasticity robust standard errors are clustered by region * year in both regressions discussed above. Given that variation is derived from fewer than 30 regions, this clustering is restrictive. Even so, the results discussed below are robust to clustering at only the region level as well as when using only heteroscedasticity robust standard errors. 


\section{Results}

\subsection{Influenza and City Spending}

This section discusses how per-capita spending on inhabitants after 1925 is related to influenza mortality during the pandemic of 1918 to 1920.

[Figures 2 and 3 about here]

Figure 2 depicts the average city's spending, per inhabitant, in a given year. Panel (a) indexes spending to 1925 while panel (b) shows average per-inhabitant spending in Reichsmark. Cities are split into three buckets based on the share of the population that died from influenza (i.e. the city's influenza mortality rate, between 1918 and 1920). The figure depicts spending for the highest and lowest buckets of influenza mortality. As can be seen, cities with lower influenza mortality rates grew their per-capita spending more, particularly during to the boom-period between 1928 and 1930. This, in turn, lead to a larger relative collapse in per-capita spending after 1930 (i.e. after the onset of the great depression). It is evident, from panel (b), that the per-capita spending of cities with lower influenza mortality was always higher in the available data. Due to data limitations, I am unable to ascertain whether this difference existed before the onset of the pandemic; as such I acknowledge difference may simply be related to city characteristics, such as its density or size.

Figure 3 formalizes the discussed analysis somewhat and controls for observable city characteristics. The figure shows that expenditure per person was related to influenza mortality, especially when accounting for the influence of city size, the percentage of the local population that was Jewish or Catholic in 1925, the share of the population that was unemployed in 1930 or 31, the share of total influenza deaths that were female, as well as city-tier and year fixed effects. Panel (a) depicts expenditure for all the years between 1925 and 1932. Panel (b) focuses only on the years following the onset of the global great depression, 1930-1932/33.

[Table 2 and 3 about here]

Table 2 presents results for the above discussion in regression form. It shows that the mortality rate of influenza had a statistically significant effect on per-capita spending, despite the small sample size and a relatively well saturated regression. All regressions include city-level wages of metal workers, regional unemployment levels in 1930 and 1931, and city-level hyper inflation controls. Column (1) makes use of the entire sample period. A one standard deviation increase in the influenza mortality rate 
is associated with a lower per capita spending of just over 4 Reichsmark. Columns (2) and (3) focus on the boom period between 1925 and 1930 and the onset of the great depression, after 1930, respectively. The results on per capita spending are stronger in the post-boom period. Column (4) makes use of the whole sample period but includes a measure of taxes collected by the city. these coefficients should be interpreted with care, given that taxes will be a function of desired spending. However, the result is robust to the inclusion of collected taxes. It suggests that, taxes held equal, affected cities were less likely to engage in borrowing to spend on their population ${ }^{14}$. Ultimately, cities with a greater number of influenza deaths, relative to their population, spent less on their population in the years after 1925.

Table 3 explores these results in more detail. Each column of Table 3 makes use of the same specification and sample as in column (1) of Table 2. However, the dependent variable is a different sub category of per-capita city expenditure. The number of observations falls a little for this analysis, given less detailed data reported by some cities. The analysis shows that the influenza mortality rate of 1918 correlated with lower spending on schools. This is true for primary schools as well as all other types of schools. Influenza mortality was also correlated with lower street maintenance expenditures, though this effect is not statistically significant. On the other hand, influenza mortality was correlated with slightly higher spending on fire brigade services and police protection (not shown) as well as on cultural institutions such as theaters and museums. These results support the notion that the pandemic changed the preferences of cities, on aggregate.

\subsection{Influenza and Extreme Voting}

This section shows that the 1932 and 1933 vote share won by extremists was related to influenza mortality of a decade earlier. The correlation was positive for right-wing extremists and negative for left-leaning extremists.

[Figure 4 about here]

Figure 4, panel (a) shows that the share of votes obtained by the National Socialist party in 1933 and 1932 is correlated with the influenza death-rate from over a decade earlier. In the elections of 1933 and 1932, the National Socialists were the clear party of the extreme right. The result holds despite the small sample. The figure represents a bin-scatter that controls for city characteristics such as size, per-capita expenditure, and the percentage of the population that is Jewish or Catholic, as well as region-level

\footnotetext{
${ }^{14}$ Tax data is not available in every year. I interpolate if tax data is not available.
} 
controls such as change in unemployment just prior to the election. The opposite seems to hold for the effect of influenza mortality on the vote share obtained by left-leaning extremist parties. The vote share obtained by the communists, as can be seen in panel (b), was negatively correlated with the influenza mortality rate of the region.

\section{[Tables 4 about here]}

The observation, that the share of the vote won by right wing extremist parties correlated with influenza mortality, can be corroborated in regressions. In Table 4, I regress the share of the vote obtained by the National Socialist party in 1933 and 1932 on a number of regional and city characteristics. Column (1) makes use of the most basic specification that includes only a measure of town size, the change in the region's population from before to just after the war (1910 to 1918), the percentage of the population that is Jewish or Catholic in 1925, the vote share won by right wing extremists in the election of 1912, the change in a city's population from just before the war to 1930, prior to the election, and the share of influenza deaths that were female. The variable of interest is the share of the regional population that died of influenza in 1918. Successive columns add additional regressors. Column (2) includes the highest rates of inflation a city experienced in 1923, the worst year of hyperinflation, as well as measures of city-spending from the year prior to the election. Spending, by itself, is a strong driver of voting behaviour and is a necessary inclusion in these regressions. Column (3) additionally includes the wages of metal workers for 1930 and the change in these wages between 1930 and 1932 at the city-level. Finally, column (4) additionally includes region-level unemployment in 1930 and 1931. In column (5), spending per inhabitant is replaced with changes in spending between 1930 and 1932.

The share of votes obtained by the National Socialist party was positively related to the share of the population that died from influenza in 1918. The baseline result remains significant in each specification. A one standard deviation increase in the share of the population that died from influenza is correlated with a between 1.6 and 2\%-pt larger vote share won by the National Socialist party. Economic controls, such as an increase in the share of the population that is unemployed or a drop in wages, are also strongly related to an increase in the share of the vote obtained by the National Socialist party; however, including such controls does not remove the direct effect of influenza mortality. 


\section{Robustness, Extensions, and Channels}

\subsection{Robustness and Alternate Specifications}

This section discusses econometric challenges and proposes possible solutions and alternate tests to corroborate the baseline result.

The analysis discussed above faces several challenges, many of which were touched upon in the introduction. Firstly, the regressions are based on a small sample of cities. Secondly, the effects of influenza mortality may be hard to disentangle from other deaths, many related to World War I, which might have had similar societal impacts. This concern may not be sufficiently circumvented by controlling for population changes between 1910 and 1918, given the many different impacts of the war. Thirdly, the granularity of the collected data is not the same across each data source. This may call into question assumptions regarding the mortality rates attributed to some areas. Finally, I may be missing key variables that drove both influenza fatality and extremist voting. For example, influenza deaths might have been affected by long-standing health issues in some communities, which might have been the result of worse access to medicine ${ }^{15}$, or worse state finances.

\section{[Table 5 about here]}

The regressions in Table 5 attempt to address the concerns relating to regional differences in access to healthcare as well as overall mortality related to un-observable regional differences. The regressions include additional controls that capture access to healthcare: pre-war regional mortality rates, information on the share of a region's population registered with a "Krankenkasse" aka health insurers, the number of doctors per 1000 inhabitants, as well as data on the per-capita income taxes collected by a state in 1920. The information on doctors is taken from a handbook for doctors issued in 1919 and 1909; it records the number of practicing physicians per 1000 inhabitants at the level of the region, in 1919, and the city, in 1909. The number of doctors may reflect how easy it was for members of a community to access health services. Insurance is usually provided by an employer or a union for workers and their families. The system is not analogous to today's systems. However, being a member of a health insurer would allow a person to more easily access healthcare services at a lower cost (from the perspective of the person seeking medical care). Finally, state taxes may be one small glimpse at

\footnotetext{
${ }^{15}$ Disease mortality was likely compounded by malnutrition and starvation of the civilian population, due in part to an Allied naval blockade during the war, which caused many long-term health problems for affected persons (see Blum (2013) or Blum (2011)).
} 
state-level wealth. ${ }^{16}$. All regressions include the full set of basic and economic controls discussed above.

In column (1), the variable of interest is still the share of the population that died from influenza, in 1918. In the remaining columns, I make use of alternate causes of death as the variables of interest. These alternate causes of death may reflect regional mortality, unrelated to the pandemic. If regional healthcare is related to underlying regional conditions, we may expect mortality of any kind to affect voting behaviour. The variables of interest are tuberculosis, accidents, and cancer deaths in 1918. Tuberculosis was still an established part of life in the early 20th century. In fact, it killed nearly as many people as influenza between 1918 and 1920. Accidents and other causes of death are tragic, and unfortunately frequent. However, they are typically not a pandemic and do not necessarily affect one part of the population disproportionately. One can see from table 5 that only the coefficient on influenza mortality remains statistically significant. A one standard deviation increase in influenza mortality leads to a $0.8 \%$-pt increase in the share of votes won by the National Socialists. Though this is smaller than in the baseline effect, discussed above, the regression is highly saturated and accounts for a host of regional differences. It is worth noting that there does exist an unconditional relationship between various forms of death and the share of votes won by extremists. This possibly signifies that access to healthcare may well matter. However, this correlation does not hold if one accounts for income, employment, or healthcare measures.

There may be other unobserved regional or city characteristics, besides access to healthcare, that affect my results. Consequently, I attempt to instrument the influenza mortality rate of 1918 in order to circumvent some of the possible endogeneity issues. I use, as instruments, the distance (in $\mathrm{km}$ ) and the density (per inhabitant) of railway lines in 1918. When controlling for the population density, wealth, and other local characteristics, one could argue that the spread of influenza would likely have been facilitated by transport and social connections. This is in keeping with evidence presented by Kuchler et al. (2020), who show that social links facilitate the spread of COVID-19.

[Table 6 about here]

It is unlikely that train line density is itself positively correlated with right-wing extremist voting. This follows from the fact that National Socialists tended to perform better in rural regions with less dense rail connections. For instance, the share of the vote won by right-wing extremists was much higher in agrarian eastern Prussia or Pommerania (nearly 60\% NS vote) than in the heavily industrialized

\footnotetext{
${ }^{16}$ I address the issue of taxes earlier, in that taxes raised may be a function of local preferences. However, state-level taxes are one layer removed from city taxes.
} 
Ruhr valley (<35\% NS vote). ${ }^{17}$ Results are depicted in Table 6 . The key variables for the first stage regression are depicted in column 1. Successive columns include different (or additional) income, unemployment or hyperinflation controls. The baseline correlations, discussed above, are corroborated by the instrumented regressions. The magnitude of the effect is larger than in the baseline specifications. This suggests that the baseline OLS-effect is possibly mitigated by other factors, such as local amenities and public services in some of the more densely populated cities. Unfortunately, given a relatively small sample size, the instrument is somewhat unstable. It performs somewhat worse, as measured by the F-statistic, as additional income or inflation controls are added.

Finally, the appendix includes variations of the baseline regression that (i) make use of additional elections as part of the sample and (ii) restrict the sample to one single year to highlight the stability of the results. The baseline estimation on the effect of influenza mortality in 1918 remains largely unchanged. The appendix also contains a discussion of the similarities between pneumonia and influenza. Even some medical experts may have had difficulty in disentangling the two. There appears to have been a small, though pronounced, increase in pneumonia deaths around the same time as the influenza pandemic raged. Given that pneumonia patients exhibited some similar symptoms, these deaths may have been mis-attributed. Influenza deaths used in this data can be viewed as a lower bound of total influenza deaths. However, if regions systematically mis-reported influenza deaths, this may bias the baseline results of the paper. As a consequence, the appendix details a set of regressions that combine pneumonia and influenza deaths (and even influenza, pneumonia, and tuberculosis) in 1918 to show that the results are driven by the rapid increase in influenza deaths.

I perform a few additional tests, which I do not include for brevity. For instance, I can show that the results are robust to removing individual regions from the regressions. This means that large states, such as Bavaria, or populated states, such as Westfalen, are not driving the result. Finally, I can show that the results hold if one uses cumulative influenza deaths between 1918-20, as opposed to 1918 alone.

\subsection{Channels}

The analyses presented above have not addressed the exact mechanism through which influenza mortality may have affected a local populations attitudes and thereby municipal spending or voting behaviour. In truth, many mechanisms could be at play simultaneously. For instance, the influenza

\footnotetext{
${ }^{17}$ Regions with denser infrastructure invest more in their population and see higher rates of influenza mortality, which in turn mitigates investment. For this reason, I control for regional expenditure in the IV regressions.
} 
pandemic may have reduced the number of members in younger generations, thereby affecting the composition of local societies ${ }^{18}$. This may lead certain generations to have a smaller voice and cities to overlook their interests. The expenditure regressions, discussed above, offer some small evidence for this channel. Alternatively, the analyses above may be picking up the interplay between deep seated anti-semitism / anti-outsider sentiment in certain regions, fears brought out by disease, and right wing propaganda.

Using concepts developed by Voigtländer and Voth (2012a), I first test whether the correlation between influenza mortality and the vote-share of right wing extremists was affected by the historical antisemitism of towns. Jewish inhabitants of towns were frequently blamed for plagues throughout history; most notably the black death in 1350 . Following the spread of the black death, many communities persecuted and killed their Jewish minority populations. Voigtländer and Voth (2012a) show that such antisemitism, at the community level, persisted until the early 20th century. It is possible that the correlation between influenza mortality and right-wing extremist voting should be greater in areas pre-disposed towards hatred of their minority population, especially following the outbreak of disease.

In a second step, I test whether this effect was further compounded by exposure to right wing propaganda. After all, right wing parties in general, and the National Socialists in particular, made use of the biological language of disease and applied it to minorities, often singling out Jews (see Bein (1966) for a discussion and Diehl (2005) for an overview of health-related propaganda ${ }^{19}$ ). The National Socialists used many different media outlets to reach a wide audience with twisted messages. Establishing the extent to which any one region may have been subjected to propaganda is difficult. However, Adena et al. (2015) show that the radio played a large role. Areas with higher historical levels of anti-semitism were more susceptible to racist ideological propaganda over the radio. Importantly, Adena et al. (2015) show that (i) the National Socialists began disseminating messages over the radio aggressively before the 1933 election but that (ii) not all regions in Germany had equal access to radios. I use the radio-subscription measures for communities from Adena et al. (2015) and interact these with influenza mortality and historical antisemitism measures to test whether radio propaganda may have exacerbated the effects for right wing voting.

\footnotetext{
${ }^{18}$ The effects of this channel would likely have been compounded by war deaths, which affected similar generations.

${ }^{19}$ See also Wright (2016) for an overview of the disease oriented propaganda after 1933 . Party members and leadership frequently linked minorities, especially Jewish communities, to disease (see:Burleigh and Wippermann (1991) or https://research.calvin.edu/german-propaganda-archive/esser.htm). Hitler made such links in speeches and writings. The earliest known instance in which he made such an explicit link came in a letter, written in 1919, while the influenza pandemic raged on (With special thanks to Rabbi Marvin Hier and the Simon Wiesenthal Center for providing a copy of the letter.).
} 
[Table 7 about here]

Table 7 shows the relationship between medieval antisemitism, influenza mortality, and the vote share obtained by the National Socialists. Here, following Voigtländer and Voth (2012a), the variable of interest (influenza mortality in 1918) is interacted with a measure of whether a community engaged in a pogrom against its Jewish population around the time of the black death in 1350. The variable is a dummy that takes the value of one if the community engaged in the murder, the expulsion, or imprisonment of members of the Jewish community. Each column contains a slightly different set of economic controls. The correlation between influenza mortality and the vote share won by right-wing extremists was greater in areas with pre-existing anti-semitism, notwithstanding the economic controls employed. While this could reflect differences in the nature of some communities that are unrelated to the factors being analyzed, this result at least offers indicative support for the thesis discussed above.

\section{[Table 8 about here]}

Furthermore, the effect of influenza mortality on right wing voting was compounded by access to radio. The triple interaction of access to radio, historical antisemitism and influenza mortality is correlated with National Socialist voting. Table 8 presents the results of this regression. Historical antisemitism takes the value of one if the community engaged in the murder, the expulsion, or imprisonment of members of the Jewish community. Access to radio is taken from Adena et al. (2015); regions with high or very high subscription density to radio are considered to have "access" to radio. The results highlight that there does exist an additional effect of radio propaganda. As in Adena et al. (2015), the propaganda was effective in regions which had traditional anti-semitic beliefs and additionally compounded by influenza mortality. The magnitude of the triple interaction accounted for a large share of the baseline effect. The cumulative effect implies an up to $1.5 \%$-pt increase in NS vote share following a one standard deviation increase in influenza mortality in regions with historic pogroms and access to radio. Interestingly, the triple interaction was not significant for earlier elections. This is further evidence that the regression is picking up the effect of propaganda, given that the National Socialists had not yet begun to use the radio to disseminate their twisted messages in any serious capacity before 1932. The table depicts only the coefficients of interest - simple interactions and other coefficients are not displayed for convenience. Unfortunately the number of observations is low given the number of controls employed, so inferences must be made with caution. 


\section{Conclusion}

Evidence suggests that the deaths brought about by the influenza pandemic of 1918-1920 may have shaped German society going forward. Regional variation in influenza mortality was related to subsequent city spending on various amenities for its population. Cities that saw a greater share of their population die due to influenza spent less, per-capita, going forward. Perhaps more importantly, influenza deaths themselves are correlated with the share of votes won by extremists, specifically the extremist National Socialist party. This effect dominates many other effects and is persistent even when controlling for the influences of local unemployment, city spending, population changes brought about by the war, and local demographics, or when instrumenting for influenza mortality.

The results are possibly a consequence of changes in societal preferences following a pandemic. In particular, the pandemic may have interacted with existing deep seated anti-semitism/anti-outsider sentiment, which was further fed by national socialist propaganda that linked diseases to minorities. Given a number of econometric challenges, care must be taken in the interpretation of the results. Nevertheless, this study offers a novel contribution to the discussion surrounding the long-term effects of pandemics. 


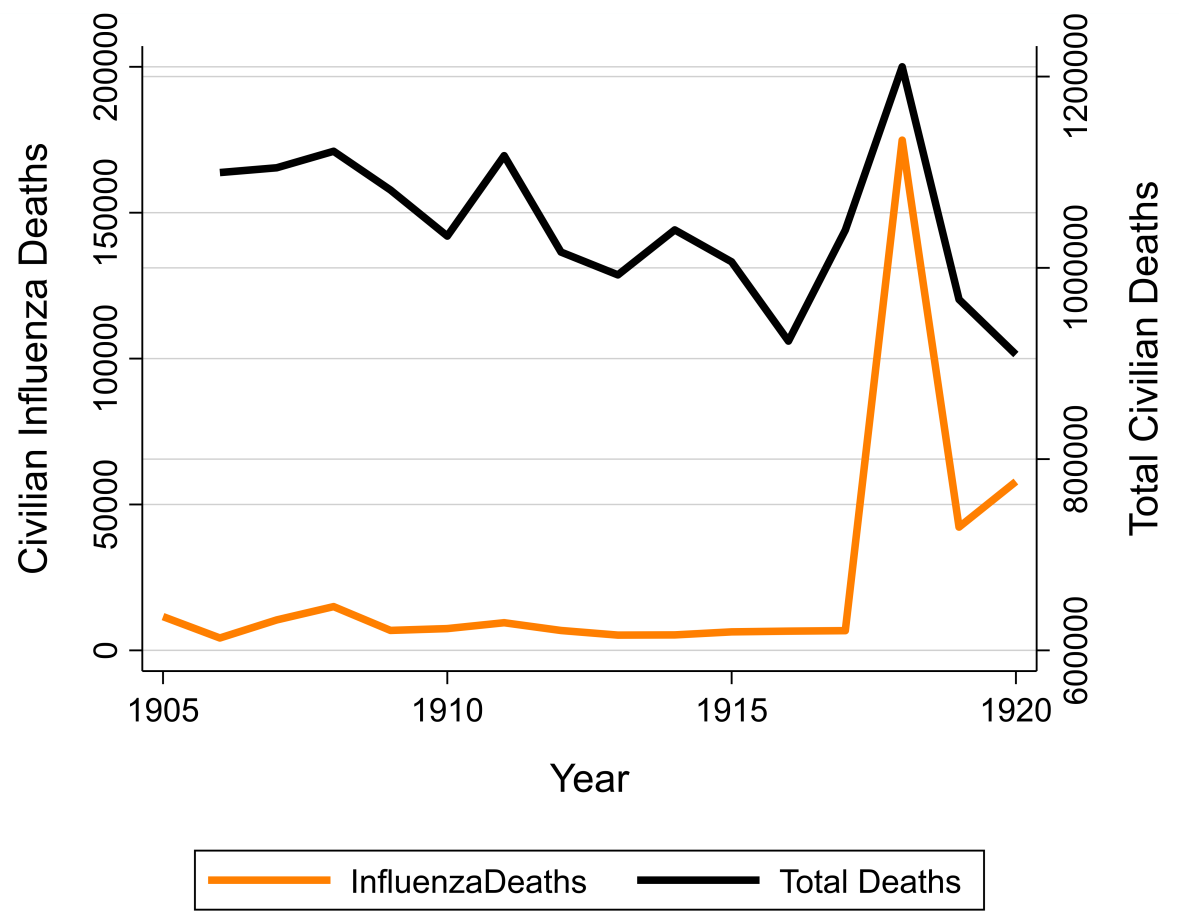

(a) Influenza spike

Figure 1: Influenza and Total Fatalities This figure depicts the total number of civilian deaths attributable to influenza (left axis) and the total number of civilian deaths attributable violence, disease, age etc. in general (right axis) over time. These figures are not inclusive of military deaths during the war.

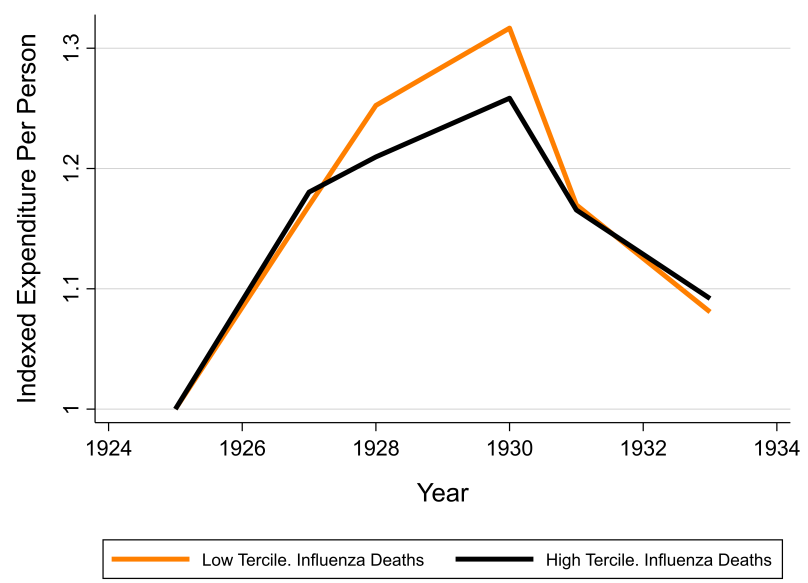

(a) Indexed spending of cities, highest vs. lowest tercile of influenza mortality.

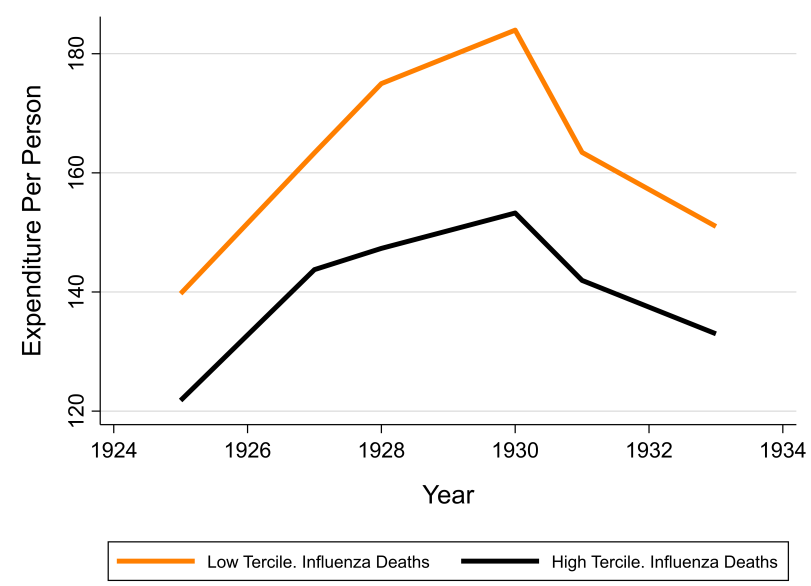

(b) Spending per inhabitant, highest vs. lowest tercile of influenza mortality.

Figure 2: City Spending over Time Average spending on inhabitants by cities in each year. Cities are split into three groups based on share of population to die from influenza in 1918-1920. Figure shows highest and lowest tercile. 


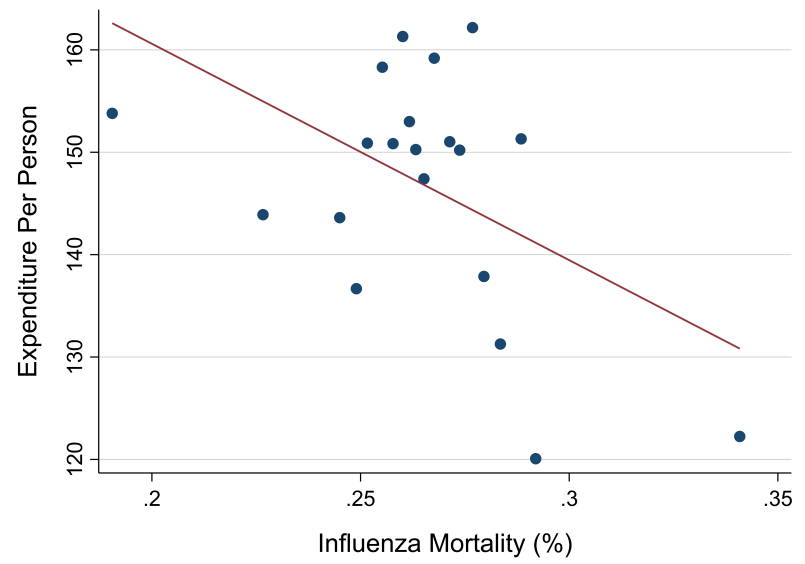

(a) Total city spending per inhabitant 1925-1932 vs. influenza mortality 1918

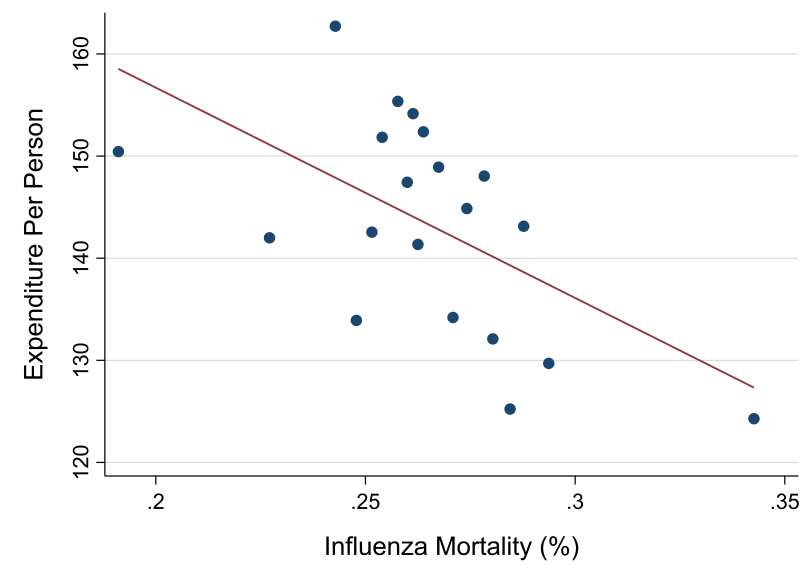

(b) Total city spending per inhabitant 1930-1932 vs. influenza mortality 1918

Figure 3: Spending v. Influenza Mortality Per-capita spending of cities. Panel (a) depicts the years 1925-1932 and panel (b) depicts the post crisis 1930-1932 period, relative to share of population that died from influenza in 1918. The scatterplot represents residuals; controls include city-tier, year, town-size, percent of local population that is Jewish and Catholic, share of population that is unemployed, and share of influenza deaths that were female.

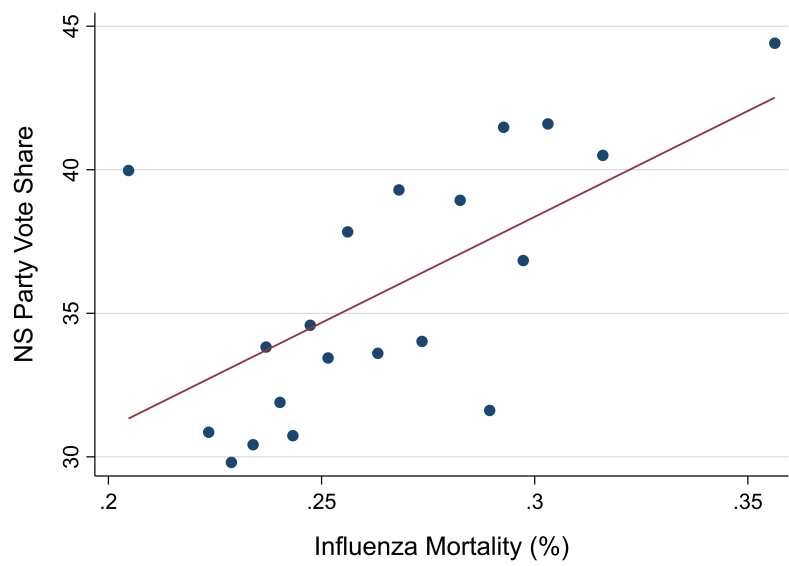

(a) Nat. Soc. vote share 1933 vs. influenza mortality 1918

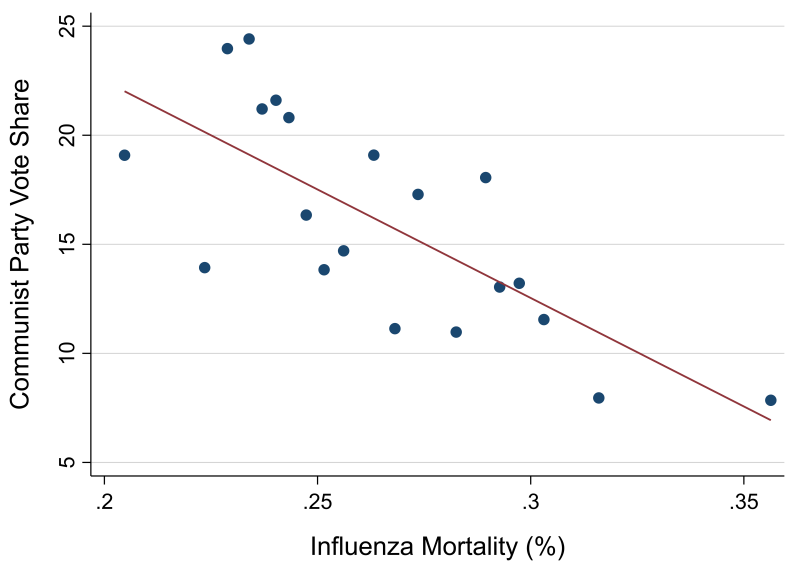

(b) Communist vote share 1933 vs. influenza mortality 1918

Figure 4: Extremist Vote Share v. Population Influenza Deaths 1918 This figure relates the share of votes obtained by the National Socialist party in 1933 (a) or the communist party in 1933 (b) to the share of the population that died from influenza in 1918. The scatterplot represents residuals; controls include city-tier, year, town-size, percent of local population that is Jewish and Catholic, share of population that is unemployed, per capita spending of city, and share of influenza deaths that were female. 
Table 1: Summay Statistics

\begin{tabular}{lccccc}
\hline \hline & & & & & \\
& $\mathrm{N}$ & Mean & StDev. & Min & Max \\
\hline NS Vote '33 & 72 & 41.08581 & 9.510717 & 24.4 & 62.4 \\
NS Vote '32 & 72 & 30.54572 & 9.88844 & 13 & 51.85 \\
Extreme vote '33 & 72 & 62.0919 & 9.897063 & 37.6 & 83.55 \\
Extreme vote '32 & 72 & 56.78361 & 10.44406 & 28.55 & 76.8 \\
Influenza mortality 1918-20 pct-pt & 72 & .438745 & .0734169 & .298394 & .7065488 \\
Influenza mortality 1918 pct-pt & 72 & .2667874 & .0478604 & .1544276 & .3882655 \\
Share of female influenza deaths & 72 & .5312397 & .0665749 & .2749166 & .5931792 \\
Spend. per inh. & 72 & 148.6411 & 31.73603 & 93.97 & 244.19 \\
Expenditure per inhabitant on schools & 48 & 23.98521 & 6.774574 & 4.79 & 37.1 \\
Expenditure per inhab. on cult./museum & 72 & 4.840139 & 4.532456 & .09 & 26.2 \\
Change in per capita spend. 1930-1932 & 71 & -.1261789 & .1470334 & -.4058214 & .2529748 \\
Log town size & 72 & 11.93866 & .8847499 & 10.88374 & 15.26724 \\
Change region pop. 1910-18 & 72 & .0369404 & .0394348 & -.0814713 & .0880026 \\
Change city pop. 1912-30 & 72 & -.2864423 & .6078174 & -.9174945 & 2.46614 \\
Percent of population Jewish & 72 & .88625 & .9813467 & .05 & 6.3 \\
Percent of population Catholic & 72 & 37.85111 & 30.59117 & 1.8 & 94.5 \\
Share unemployed pop. '31 & 72 & .0818793 & .024945 & .0369189 & .2208258 \\
Share of unemployed pop. '30 & 72 & .053191 & .0182976 & .0292761 & .1487352 \\
Log change unemployment 30-31 & 72 & .4374324 & .1482857 & .2319517 & .6601584 \\
City-level wage of metalworkers 1932 & 72 & 75.975 & 5.389028 & 64.8 & 90.2 \\
City-level wage of metalworkers 1930 & 72 & 93.51667 & 6.536097 & 80.9 & 110 \\
Highest inflation 1923 (in Tsd pct) & 72 & 130.5146 & 25.06138 & 97.443 & 182.499 \\
\hline \hline
\end{tabular}

Note: This table shows summary statistics for key variables. The year of reference for the table is 1931 (unless otherwise specified). Data is available for between 72 and 76 distinct cities per year with certain spending data being available in somewhat fewer cities. 
Table 2

\begin{tabular}{|c|c|c|c|c|}
\hline & (1) & $(2)$ & (3) & (4) \\
\hline & Spend. per inh. & Spend. per inh. & Spend. per inh. & Spend. per inh. \\
\hline \multirow[t]{2}{*}{ Influenza mortality 1918} & $-100.1^{* * *}$ & -45.48 & $-110.2^{* *}$ & $-100.8^{* * *}$ \\
\hline & [35.91] & [62.81] & [48.42] & [27.79] \\
\hline \multirow[t]{2}{*}{ Share of female influenza deaths } & $-69.79 * *$ & -63.57 & -49.81 & $-63.54^{* *}$ \\
\hline & [29.67] & [45.70] & [47.23] & [26.60] \\
\hline \multirow[t]{2}{*}{ Log town size } & -1.015 & -6.614 & 9.871 & $16.00^{* * *}$ \\
\hline & [5.452] & [7.985] & [10.26] & [5.214] \\
\hline \multirow[t]{2}{*}{ Percent of population Jewish } & $12.39^{* * *}$ & $12.70^{* * *}$ & $10.38^{* * *}$ & $8.392^{* * *}$ \\
\hline & [2.001] & [2.595] & [3.387] & [1.784] \\
\hline \multirow[t]{2}{*}{ Percent of population Catholic } & $-0.117^{* * *}$ & -0.0882 & $-0.146^{* *}$ & $-0.116^{* * *}$ \\
\hline & {$[0.0421]$} & {$[0.0673]$} & {$[0.0603]$} & [0.0359] \\
\hline \multirow[t]{2}{*}{ Change city pop. $1912-18$} & $10.67^{* * *}$ & $12.68^{* * *}$ & 7.829 & $10.07^{* * *}$ \\
\hline & [3.203] & [4.280] & [5.333] & {$[2.814]$} \\
\hline Wage Controls & Yes & Yes & Yes & Yes \\
\hline Employment Controls & Yes & Yes & Yes & Yes \\
\hline Hyperinflation Controls & Yes & Yes & Yes & Yes \\
\hline $\mathrm{R}^{2}$ & .5767756 & .5879486 & .5315909 & .6522541 \\
\hline $\mathrm{N}$ & 397 & 179 & 145 & 397 \\
\hline
\end{tabular}

Note: This table shows the coefficients for equation:

$$
\text { Spending }_{c, r, t}=\beta_{0}+\beta_{l} \text { InfluenzaMortality } y_{r, 1918}+\mathbf{X}_{c}+\theta_{t}+\xi_{r}+\epsilon_{c, t},
$$

The dependent variable is the city's total spending per inhabitant. The coefficients of interest are region-level influenza mortality rates, as a share of the population, in 1918. All specifications include city-tier and year fixed effects. Column (1) makes use of all available years, column (2) focuses on pre-1929 years (i.e. the boom period) while column (3) focuses on the post 1929 period. Column (4) includes city-level per capita taxes. Wage controls are city-level wages for metal workers in 1930 and 1932. Employment controls are regional unemployment in 1930 and the change in unemployment to year-end 1931. Hyperinflation controls reflect the highest level of inflation, relative to a pre-war level of 1913/14, that a city experienced in 1923. Robust standard errors are clustered at the Region*Year level and in parentheses; $* * *$, and ${ }^{* *}$ indicate significance at the $10 \%, 5 \%$, and $1 \%$ level, respectively. 
Table 3

\begin{tabular}{|c|c|c|c|c|c|}
\hline & $(1)$ & (2) & (3) & $(4)$ & (5) \\
\hline & Cult. Inst. & Fire. Dep. & Prim. School. & All School & Street Maint. \\
\hline \multirow[t]{2}{*}{ Influenza mortality 1918} & $13.74^{* *}$ & $1.603^{*}$ & $-38.91^{* * *}$ & $-68.28^{* * *}$ & -1.592 \\
\hline & [6.110] & [0.916] & {$[6.054]$} & [17.46] & {$[4.600]$} \\
\hline \multirow[t]{2}{*}{ Share of female influenza deaths } & -0.635 & -0.759 & $-20.86^{* * *}$ & $-22.96^{* * *}$ & -1.685 \\
\hline & [4.692] & [0.997] & [4.763] & [8.785] & {$[3.554]$} \\
\hline \multirow[t]{2}{*}{ Log town size } & -1.061 & 0.109 & $-2.534^{* * *}$ & $-4.810^{* * *}$ & -0.113 \\
\hline & [0.695] & [0.102] & {$[0.654]$} & [1.377] & {$[0.501]$} \\
\hline \multirow[t]{2}{*}{ Percent of population Jewish } & 0.115 & -0.00632 & $1.057^{* * *}$ & $1.841^{* * *}$ & -0.0170 \\
\hline & [0.369] & {$[0.0374]$} & {$[0.190]$} & [0.389] & {$[0.194]$} \\
\hline \multirow[t]{2}{*}{ Percent of population Catholic } & 0.00565 & $-0.00846^{* * *}$ & 0.00425 & $-0.0629 * * *$ & $0.00977^{*}$ \\
\hline & [0.00677] & [0.00107] & [0.00727] & [0.0127] & {$[0.00535]$} \\
\hline \multirow[t]{2}{*}{ Change city pop. 1912-18 } & 0.00108 & $0.257^{* * *}$ & -0.421 & 0.747 & 0.409 \\
\hline & [0.375] & {$[0.0844]$} & [0.439] & [1.461] & [0.269] \\
\hline Wage Controls & Yes & Yes & Yes & Yes & Yes \\
\hline Employment Controls & Yes & Yes & Yes & Yes & Yes \\
\hline Hyperinflation Controls & Yes & Yes & Yes & Yes & Yes \\
\hline $\mathrm{R}^{2}$ & .2212825 & .6635528 & .5881804 & .5347453 & .4788094 \\
\hline $\mathrm{N}$ & 346 & 331 & 396 & 281 & 344 \\
\hline
\end{tabular}

Note: This table shows the coefficients for equation:

$$
\text { Spending }{ }_{c, r, t}=\beta_{0}+\beta_{l} \text { InfluenzaMortality } r_{r, 1918}+\mathbf{X}_{c}+\theta_{t}+\xi_{r}+\epsilon_{c, t}
$$

The dependent variable is the city's spending, per inhabitant, on a number of different expenditure categories. The coefficients of interest are region-level influenza mortality rates, as a share of the population, in 1918. The specification includes city-tier and year fixed effects. Wage controls are city-level wages for metal workers in 1930 and 1932. Employment controls are regional unemployment in 1930 and the change in unemployment to year-end 1931. Hyperinflation controls reflect the highest level of inflation, relative to a pre-war level of 1913/14, that a city experienced in 1923. Robust standard errors are clustered at the Region*Year level and in parentheses; ***, and *** indicate significance at the $10 \%, 5 \%$, and $1 \%$ level, respectively. 
Table 4

\begin{tabular}{lccccc}
\hline \hline & $(1)$ & $(2)$ & $(3)$ & $(4)$ & $(5)$ \\
& NS Vote & NS Vote & NS Vote & NS Vote & NS Vote \\
\hline Influenza mortality 1918 & $52.18^{* * *}$ & $50.05^{* * *}$ & $49.93^{* * *}$ & $40.82^{* * *}$ & $43.10^{* * *}$ \\
& {$[7.145]$} & {$[8.488]$} & {$[8.031]$} & {$[12.78]$} & {$[13.06]$} \\
& & & & & \\
Spend. per inh. & & -0.0158 & -0.0184 & -0.0216 & \\
& & {$[0.0204]$} & {$[0.0208]$} & {$[0.0229]$} & \\
Change in per capita spend. 1930-1932 & & & & & -4.627 \\
& & & & & {$[3.454]$} \\
\hline \hline Basic Controls & Yes & Yes & Yes & Yes & Yes \\
Wage Controls & No & No & Yes & Yes & Yes \\
Employment Controls & No & No & No & Yes & Yes \\
Hyperinflation Controls & No & Yes & Yes & Yes & Yes \\
$\mathrm{R}^{2}$ & 0.762 & 0.758 & 0.759 & 0.776 & 0.776 \\
$\mathrm{~N}$ & 155 & 149 & 149 & 147 & 146 \\
\hline \hline
\end{tabular}

Note: This table shows the coefficients for equation:

$$
\text { ExtremistVote }_{c, r, t}=\beta_{0}+\beta_{l} \text { InfluenzaMortality } r, 1918+\beta_{2} \text { CitySpending }_{c, t}+\mathbf{X}_{c}+\theta_{t}+\xi_{r}+\epsilon_{c, t},
$$

The sample encompasses the years 1932 and 1933. Extremist Vote tracks the share of votes obtained by the National Socialist party in 1932, and 1933. The coefficients of interest are $\beta_{1}$ which show the impact of the influenza mortality rate in 1918. The specification includes city-tier and year fixed effects. Basic controls include share of influenza deaths that were female, town size, change in regional population between 1910 and 1918, change in city level population between 1912 and 1930, percentage of the population that was Catholic or Jewish in 1925, the share of right wing extremists in 1912. Wage controls are city-level wages for metal workers in 1930 and 1932. Employment controls are regional unemployment in 1930 and the change in unemployment to year-end 1931. Hyperinflation controls reflect the highest level of inflation, relative to a pre-war level of 1913/14, a city experienced in 1923. Robust standard errors are clustered at the Region*Year level and in parentheses; ${ }^{*}, *$, and *** indicate significance at the $10 \%, 5 \%$, and $1 \%$ level, respectively. 
Table 5

\begin{tabular}{|c|c|c|c|c|}
\hline & $(1)$ & (2) & (3) & $(4)$ \\
\hline & NS Vote & NS Vote & NS Vote & NS Vote \\
\hline \multirow[t]{2}{*}{ Influenza mortality 1918} & $19.79^{* *}$ & & & \\
\hline & [7.847] & & & \\
\hline \multirow[t]{2}{*}{ Tuberculosis mortality 1918} & & 16.51 & & \\
\hline & & [28.28] & & \\
\hline \multirow[t]{2}{*}{ Accident mortality 1918} & & & -18.92 & \\
\hline & & & [21.24] & \\
\hline \multirow[t]{2}{*}{ Cancer mortality 1918} & & & & 3826.6 \\
\hline & & & & [2644.8] \\
\hline \multirow[t]{2}{*}{ Aggregate mortality rate 1911} & 113.7 & -29.57 & -3.876 & 83.26 \\
\hline & [150.3] & [159.8] & [149.5] & [196.7] \\
\hline \multirow[t]{2}{*}{ Doctors per Tsd. Inhab. 1919} & -0.105 & 0.0555 & -0.142 & -0.0926 \\
\hline & {$[0.744]$} & {$[0.798]$} & {$[0.742]$} & {$[0.804]$} \\
\hline \multirow[t]{2}{*}{ Doctors per Tsd. Inhab. 1909} & 11668.2 & 8935.0 & 2938.7 & 4628.6 \\
\hline & [9963.1] & [11704.6] & {$[13555.5]$} & [9908.2] \\
\hline \multirow[t]{2}{*}{ Pct. pop. insured } & 20.07 & 26.73 & $46.35^{* *}$ & 27.68 \\
\hline & [13.44] & [27.16] & [17.65] & {$[18.66]$} \\
\hline \multirow[t]{2}{*}{ Population density 1910} & 0.0000704 & -0.000194 & -0.000158 & -0.000146 \\
\hline & {$[0.000220]$} & [0.000188] & {$[0.000176]$} & {$[0.000211]$} \\
\hline \multirow[t]{2}{*}{ Percapita collected taxes } & -1.362 & 9.265 & 21.03 & 10.50 \\
\hline & [17.13] & {$[16.78]$} & [18.94] & {$[16.62]$} \\
\hline Basic Controls & Yes & Yes & Yes & Yes \\
\hline Wage Controls & Yes & Yes & Yes & Yes \\
\hline Unemployment Controls & Yes & Yes & Yes & Yes \\
\hline Hyperinflation Controls & Yes & Yes & Yes & Yes \\
\hline $\mathrm{R}^{2}$ & .815266 & .8097949 & .8099892 & .812115 \\
\hline $\mathrm{N}$ & 145 & 145 & 145 & 145 \\
\hline
\end{tabular}

Note: This table shows the coefficients for equation:

ExtremistVote $_{c, r, t}=\beta_{0}+\beta_{l}$ Mortality $_{r, 1918}+\beta_{2}$ CitySpending $_{c, 1930-32}+\mathbf{X}_{c}+$ HealthCare $_{c}+\theta_{t}+\xi_{r}+\epsilon_{c, t}$,

The sample encompasses the years 1932 and 1933. Extremist Vote tracks the share of votes obtained by the National Socialist party. The coefficients of interest are $\beta_{1}$, which show the impact of the share of the local population to die from influenza (column 1), tuberculosis (column 2), accidents (column 3), or cancer (column 4) in 1918. The specification includes city-tier and year fixed effects. Basic controls include share of influenza deaths that were female, town size, change in regional population between 1910 and 1918, change in city level population between 1912 and 1930, percentage of the population that was Catholic or Jewish in 1925, the share of right wing extremists 
in 1912. Wage controls are city-level wages for metal workers in 1930 and 1932. Employment controls are regional unemployment in 1930 and the change in unemployment to year-end 1931. Hyperinflation controls reflect the highest level of inflation, relative to a pre-war level of 1913/14, that a city experienced in 1923. Robust standard errors are clustered at the Region*Year level and in parentheses; ${ }^{*} * *$, and $* * *$ indicate significance at the $10 \%, 5 \%$, and $1 \%$ level, respectively. 
Table 6

\begin{tabular}{|c|c|c|c|c|}
\hline & (1) & (2) & (3) & (4) \\
\hline & Influenza mortality 1918 & NS Vote & NS Vote & NS Vote \\
\hline \multirow[t]{2}{*}{ State owned railway $(\mathrm{km})$} & $0.0000147^{* * *}$ & & & \\
\hline & {$[0.00000470]$} & & & \\
\hline \multirow[t]{2}{*}{ Railway km per cap. } & $0.000906^{* * *}$ & & & \\
\hline & [0.000322] & & & \\
\hline \multirow[t]{2}{*}{ Influenza mortality 1918} & & $49.15^{* * *}$ & $65.95^{* * *}$ & $81.01^{* *}$ \\
\hline & & [19.04] & [19.85] & [40.81] \\
\hline \multirow[t]{2}{*}{ Spend. per inh. } & $0.000259^{*}$ & -0.0215 & -0.0269 & -0.00103 \\
\hline & {$[0.000135]$} & [0.0237] & [0.0254] & [0.0253] \\
\hline \multirow[t]{2}{*}{ Population density } & $-0.00000315^{* * *}$ & $0.000292^{*}$ & & \\
\hline & [0.000000798] & [0.000157] & & \\
\hline Basic Controls & Yes & Yes & Yes & Yes \\
\hline Wage Controls & Yes & Yes & Yes & Yes \\
\hline Employment Controls & No & No & No & Yes \\
\hline Hyperinflation Controls & No & No & Yes & No \\
\hline rk LM stat & & 26.7 & 24.9 & 11.7 \\
\hline rk Wald F stat & & 74.3 & 56.8 & 16.4 \\
\hline$R^{2}$ & .382038 & .756254 & .7384148 & .7534859 \\
\hline $\mathrm{N}$ & 159 & 157 & 147 & 155 \\
\hline
\end{tabular}

Note: This table shows the coefficients for a two-staged least squares regression. Instruments for influenza mortality are the distance (in $\mathrm{km}$ ) and density (per inhabitant) of train lines in 1918. Extremist Vote tracks the share of votes obtained by the National Socialist party. The specification includes city-tier and year fixed effects. Basic controls include share of influenza deaths that were female, town size, change in regional population between 1910 and 1918, change in city level population between 1912 and 1930, percentage of the population that was Catholic or Jewish in 1925, the share of right wing extremists in 1912. Wage controls are city-level wages for metal workers in 1930 and 1932. Employment controls are regional unemployment in 1930 and the change in unemployment to year-end 1931. Hyperinflation controls reflect the highest level of inflation, relative to a pre-war level of 1913/14, a city experienced in 1923. Robust standard errors in parentheses; ${ }^{* *}$, and ${ }^{* * *}$ indicate significance at the $10 \%, 5 \%$, and $1 \%$ level, respectively. 
Table 7

\begin{tabular}{lcccc}
\hline \hline & $(1)$ & $(2)$ & $(3)$ & $(4)$ \\
& NS Vote & NS Vote & NS Vote & NS Vote \\
\hline Influenza mortality 1918 & $35.66^{* * *}$ & $37.84^{* * *}$ & $33.50^{* * *}$ & $33.81^{* * *}$ \\
& {$[8.360]$} & {$[5.780]$} & {$[7.850]$} & {$[8.424]$} \\
& & & & \\
Interaction: Pogrom * Influenza Mortality & $154.2^{* * *}$ & $110.3^{* *}$ & $110.2^{* * *}$ & $172.7^{* * *}$ \\
& {$[43.76]$} & {$[44.28]$} & {$[40.05]$} & {$[46.76]$} \\
& & & & \\
Pogrom 1350 & $-44.80^{* * *}$ & $-31.04^{* *}$ & $-32.30^{* *}$ & $-49.29^{* * *}$ \\
& {$[12.81]$} & {$[13.13]$} & {$[12.11]$} & {$[14.08]$} \\
Spend. per inh. & -0.0348 & -0.0142 & -0.0179 & -0.0281 \\
& {$[0.0212]$} & {$[0.0199]$} & {$[0.0247]$} & {$[0.0218]$} \\
\hline Basic Controls & Yes & Yes & Yes & Yes \\
Wage Controls & No & Yes & No & Yes \\
Unemployment Controls & Yes & No & No & Yes \\
Hyperinflation Controls & No & No & Yes & Yes \\
$\mathrm{R}^{2}$ & 0.783 & 0.763 & 0.747 & 0.791 \\
$\mathrm{~N}$ & 155 & 157 & 151 & 149 \\
\hline \hline
\end{tabular}

Note: This table shows the coefficients for equation:

ExtremistVote $_{c, r, t}=\beta_{0}+\beta_{l}$ InfluenzaMortality $_{r, 1918}+\beta_{2}$ Pogrom $_{1350} *$ InfluenzaMortality $_{r, 1918}+\beta_{3}$ Pogrom $_{1350}+\mathbf{X}_{c}+\theta_{t}+\xi_{r}+\epsilon_{c, t}$,

The sample encompasses the years 1932 and 1933. Extremist Vote tracks the share of votes obtained by the National Socialist party. The coefficients of interest are $\beta_{1}$ which shows the impact of the share of the local population to die from influenza in 1918 and $\beta_{2}$, the coefficient on the interaction of influenza mortality and a dummy, denoting whether the city engaged in medieval pogroms against its Jewish minority after the plague. The specification includes city-tier and year fixed effects. Basic controls include share of influenza deaths that were female, town size, change in regional population between 1910 and 1918, change in city level population between 1912 and 1930, percentage of the population that was Catholic or Jewish in 1925, the share of right wing extremists in 1912. Wage controls are city-level wages for metal workers in 1930 and 1932. Employment controls are regional unemployment in 1930 and the change in unemployment to year-end 1931. Hyperinflation controls reflect the highest level of inflation, relative to a pre-war level of 1913/14, a city experienced in 1923. Robust standard errors are clustered at the Region*Year level and in parentheses; ${ }^{*}, * *$, and ${ }^{* * *}$ indicate significance at the $10 \%, 5 \%$, and $1 \%$ level, respectively. 
Table 8

\begin{tabular}{|c|c|c|c|c|}
\hline & $(1)$ & $(2)$ & (3) & (4) \\
\hline & NS Vote '33 & NS Vote '33 & NS Vote '33 & NS Vote ' 32 \\
\hline \multirow[t]{2}{*}{ Influenza mortality 1918} & $32.97^{* *}$ & $27.98^{*}$ & $31.79^{* *}$ & $31.78^{* *}$ \\
\hline & [13.32] & [14.55] & [13.57] & {$[13.21]$} \\
\hline \multirow[t]{2}{*}{ High share radio ownership } & -8.824 & -4.179 & -4.177 & 1.209 \\
\hline & [7.252] & [6.812] & [7.289] & [8.817] \\
\hline \multirow[t]{2}{*}{ Int: High radio * Influenza mort. 1918} & 17.39 & 0.206 & 0.350 & -21.72 \\
\hline & [28.39] & [26.82] & [27.99] & {$[33.05]$} \\
\hline \multirow[t]{2}{*}{ Pogrom 1350} & $-66.64^{* * *}$ & $-63.20^{* * *}$ & $-60.76^{* * *}$ & $-37.19^{*}$ \\
\hline & [13.09] & [11.47] & [13.64] & {$[21.73]$} \\
\hline \multirow[t]{2}{*}{ Int: High radio * Pogrom 1350 * Influenza mort. 1918} & $35.95^{* * *}$ & $31.76^{*}$ & $30.33^{* *}$ & 0.0143 \\
\hline & [12.87] & [16.48] & [14.46] & [17.23] \\
\hline Basic Controls & Yes & Yes & Yes & Yes \\
\hline Wage Controls & No & No & Yes & Yes \\
\hline Unemployment Controls & No & No & No & No \\
\hline Hyperinflation Controls & No & Yes & Yes & Yes \\
\hline $\mathrm{R}^{2}$ & 0.660 & 0.684 & 0.712 & 0.777 \\
\hline $\mathrm{N}$ & 72 & 69 & 69 & 69 \\
\hline
\end{tabular}

Note: This table shows the coefficients for variants of the baseline equation that additionally includes a triple interaction term of access to radio, historical antisemitism, and influenza mortality. The sample is either the election of 1933, before which national socialist propaganda had become common, and earlier elections. The specification includes city-tier and year fixed effects. Basic controls include share of influenza deaths that were female, town size, change in regional population between 1910 and 1918, change in city level population between 1912 and 1930, percentage of the population that was Catholic or Jewish in 1925 as well as the vote share of right wing parties in 1912. Wage controls are city-level wages for metal workers in 1930 and 1932. Employment controls are regional unemployment in 1930 and the change in unemployment to year-end 1931. Hyperinflation controls reflect the highest level of inflation, relative to a pre-war level of $1913 / 14$, a city experienced in 1923 . Robust standard errors in parentheses; ${ }^{*}, * *$, and ${ }^{* *}$ indicate significance at the $10 \%, 5 \%$, and $1 \%$ level, respectively. 


\section{References}

Adena, M., R. Enikolopov, M. Petrova, V. Santarosa, and E. Zhuravskaya (2015). Radio and the rise of the Nazis in prewar Germany. Quarterly Journal of Economics.

Alfaro, L., A. Chari, A. Greenland, and P. Schott (2020). Aggregate and firm-level stock returns during pandemics, in real time. NBER Working Paper 26950.

Almond, D. (2006). Is the 1918 influenza pandemic over? long-term effects of in utero influenza exposure in the post-1940 u.s. population. Journal of Political Economy 114(4), 672-712.

Atkeson, A. (2020). What will be the economic impact of covid-19 in the us? rough estimates of disease scenarios. NBER Working Paper 26867.

Barro, R., J. Ursúa, and J. Weng (2020). The coronavirus and the great influenza pandemic: Lessons from the "spanish flu" for the coronavirus's potential effects on mortality and economic activity. NBER Working Paper 26866.

Bartik, A., M. Bertrand, Z. Cullen, E. Glaeser, M. Luca, and C. Stanton (2020). How are small businesses adjusting to covid-19? early evidence from a survey. NBER Working Paper 26989.

Bein, A. (1966). Bemerkungen zur Semantik der Judenfrage.

Blum, M. (2011). Government decisions before and during the first world war and the living standards in germany during a drastic natural experiment. Explorations in Economic History 48.

Blum, M. (2013). War, food rationing, and socioeconomic inequality in germany during the first world war. The Economic History Review 66.

Born, K. E. (1967). Die Deutsche Bankenkrise 1931. Piper \& Co. Verlag.

Brainerd, E. and M. Siegler (2003). The economic effects of the 1918 influenza epidemic. CEPR Discussion Paper Series 3791.

Burleigh, M. and W. Wippermann (1991). The Racial State: Germany 1933-1945. Cambridge University Press.

Bursztyny, L., Raoz, C. A. Rothx, and D. Yanagizawa-Drott (2020). Misinformation during a pandemic. Mimeo. 
Cohn, S. (2012). Pandemics: waves of disease, waves of hate from the plague of athens to a.i.d.s. Historical Research 85(230).

Correira, S., S. Luck, and E. Verner (2020). Pandemics Depress the Economy, Public Health Interventions Do Not: Evidence from the 1918 Flu. Mimeo.

Diehl, P. (2005). Macht - Mythos - Utopie. Akademie Verlag.

Doerr, S., S. Gissler, J. L. Peydró, and J. Voth (2020). From finance to fascism. CEPR Discussion Paper DP12806.

Eichenbaum, M., S. Rebelo, and M. Trabandt (2020). The macroeconomics of epidemics. NBER Working Paper No. 26882.

Eichengreen, B. (2018). The populist temptation: economic grievance and political reaction in the modern era. Oxford University Press.

Ferguson, N. (1996). Constraints and room for manoeuvre in the German inflation of the early 1920s. Economic History Review 49.

Ferguson, N. (1997). The German inter-war economy: political choice versus economic determinism, in: German history since 1800. Arnold.

Ferguson, T. and H.-J. Voth (2008). Betting on hitler-the value of political connections in nazi germany. Quarterly Journal of Economics.

Galofré-Vilà, G., C. Meissner, M. McKee, and D. Stuckler (2019). Austerity and the rise of the nazi party. NBER Working Paper, No. 24106.

Garrett, T. (2008). Pandemic economics: The 1918 influenza and its modern-day implications. Federal Reserve Bank of St. Louis Review 90.

Geary, D. (2002). Nazis and workers before 1933. Australian Journal of Politics and History 15796.

Guimbeau, A., N. Menon, and A. Musacchio (2020). The brazilian bombshell? the long-term impact of the 1918 influenza pandemic the south american way. NBER Working Paper Series 26929.

Hamermesh, D. (2020). Lock-downs, loneliness and life satisfaction. NBER Working Paper Series 27018. 
Haverkamp, A. (2002). Geschichte der Juden im Mittelalter von der Nordsee bis zu den Südalpen; Kommentiertes Kartenwerk.

Hoffmann, W. G. (1965). Das Wachstum der deutschen Wirtschaft seit der Mitte des 19. Jahrhunderts. Springer-Verlag.

Huber, K., V. Lindenthal, and F. Waldinger (2019). Discrimination, managers, and firm performance: Evidence from "aryanizations" in nazi germany. CEPR Discussion Paper DP13089.

James, H. (1986). The German slump: politics and economics 1924-1936. Oxford University Press.

Kuchler, T., R. Dominic, and J. Stroebel (2020). The geographic spread of covid-19 correlates with structure of social networks as measured by facebook. NBER Working Paper 26990.

MacKellar, L. (2007). Pandemic Influenza: A Review. Population and Development Review 33(3).

Markel, H., J. Lipman, A. Navarro, J. Sloan, A. Michalsen, A. Stern, and M. Cetron (2007). Nonpharmaceutical interventions implemented by us cities during the 1918-1919 influenza pandemic. JAMA 298.

Markowitz, S., E. Nesson, and J. Robinson (2018). The effects of employment on influenza rates. NBER Working Paper Series 15796.

Pettit, D. (1976). A cruel wind: America experiences pandemic influenza, 1918-1920 a social history. University of New Hampshire Scholars' Repository.

Satyanath, S., N. Voigtlaender, and H.-J. Voth (2017). Bowling for fascism: Social capital and the rise of the nazi party in weimar germany, 1919-33. Journal of Political Economy.

Straumann, T. (2019). Debt, Crisis, and the rise of Hitler. Oxford University Press.

Temin, P. (1971). The beginning of the Depression in Germany. Economic History Review 24.

Temin, P. (1990). Lessons from the Great Depression. MIT Press.

Voigtlaender, N. and H.-J. Voth (2014). Highway to hitler. NBER Working Paper 20150(1).

Voigtländer, N. and H. Voth (2012a). Persecution perpetuated: The medieval origins of anti-semitic violence in nazi germany. Quarterly Journal of Economics 127(3). 
Voigtländer, N. and H. Voth (2012b). Re-shaping hatred: Anti-semitic attitudes in germany, 1890-2006. CEPR Discussion Paper 8935.

Wright, M. (2016). Metaphors of Health and Disease in Nazi Film Propaganda. Amazon Publishing. 


\title{
Appendix for "Pandemics Change Cities"
}

\author{
Kristian Blickle
}

\section{A Data}

Table A.1: Data Sources

\begin{tabular}{|c|c|c|c|}
\hline Data & Source (Engl.) & Source (German) & Granularity \\
\hline Influenza Mortality & $\begin{array}{l}\text { Annual statistics } \\
\text { of the German Reich }\end{array}$ & $\begin{array}{l}\text { Statistisches Jahrbuch } \\
\text { fuer das Deutsche Reich }\end{array}$ & $\begin{array}{c}\text { State and Prussian } \\
\text { "Regions" }\end{array}$ \\
\hline City Spending & $\begin{array}{l}\text { Annual statistics } \\
\text { for German cities }\end{array}$ & $\begin{array}{l}\text { Statistisches Jahrbuch } \\
\text { Deutscher Staedte }\end{array}$ & City \\
\hline Unemployment Data & $\begin{array}{l}\text { Annual statistics } \\
\text { of the German Reich }\end{array}$ & $\begin{array}{l}\text { Statistisches Jahrbuch } \\
\text { fuer das Deutsche Reich }\end{array}$ & $\begin{array}{c}\text { State and Prussian } \\
\text { "Regions" }\end{array}$ \\
\hline Wage Data & $\begin{array}{l}\text { Annual statistics } \\
\text { of the German Reich }\end{array}$ & $\begin{array}{l}\text { Statistisches Jahrbuch } \\
\text { fuer das Deutsche Reich }\end{array}$ & City \\
\hline Inflation Data & Economy and Statistics & Wirtschaft und Statistik & City \\
\hline Election Data & ICPSR & ICPSR & City/Neighborhood \\
\hline Population data (region) & $\begin{array}{l}\text { Annual statistics } \\
\text { of the German Reich }\end{array}$ & $\begin{array}{l}\text { Statistisches Jahrbuch } \\
\text { fuer das Deutsche Reich }\end{array}$ & $\begin{array}{c}\text { State and Prussian } \\
\text { "Regions" }\end{array}$ \\
\hline Population data (city) & $\begin{array}{l}\text { Annual statistics } \\
\text { for German cities }\end{array}$ & $\begin{array}{l}\text { Statistisches Jahrbuch } \\
\text { Deutscher Staedte }\end{array}$ & City \\
\hline Railway Data & $\begin{array}{l}\text { Annual statistics } \\
\text { of the German Reich }\end{array}$ & $\begin{array}{l}\text { Statistisches Jahrbuch } \\
\text { fuer das Deutsche Reich }\end{array}$ & $\begin{array}{c}\text { State and Prussian } \\
\text { "Regions" }\end{array}$ \\
\hline Pogrom data & Voigtländer and Voth (2012a) & NA & City \\
\hline Radio subs. data & Adena et al. (2015) & NA & City \\
\hline
\end{tabular}

Note: This table shows the source and granularity of major data sources used in the paper. 
Table A.1 depicts the sources and granularity of the data used in this paper. Important variation is either derived at the region or city-level. The cities listed in the monthly statistics publications, which detail hyperinflation, are not always the same as the cities for which spending data is available. If there is no direct match, as is the case for 15 cities, the nearest city, geographically, is used.

Figure A.1, depicts the full set of cities used in the paper on a map of Germany from 1922. The map also depicts "region" boundaries used in the paper. These are either states, city states, or administrative regions within Prussia. The map uses city boundaries to place a city. Some cities are considerably larger than their population might suggest, based on historical borders. Clusters of cities can be seen in the north-west (the upper Rhineland and Westfalia) as well as in a few other places across Germany (for example in Hessia).

Panel B of Figure A.1 shows the share of the population that died from influenza in 1918 for the regions across Germany. The highest levels of influenza mortality can be observed in the regions of upper Silesia with a mortality rate of over $0.4 \%$. I omit this region from the majority of analyses discussed above (and therefore do not include it as a maximum in the legend) because the region was partly contested by Poland (large parts of the region had to decide by plebiscite whether to remain German or become Polish). Given that the region contains only one city of relevance to the paper it can be ignored. High influenza mortality rates are also observed in the North-Eastern regions of eastern Prussia and Pomerania, which would see a large share of votes go to right-wing extremists, as well as areas such as Braunschweig, which saw a smaller share of the vote go to national socialists.

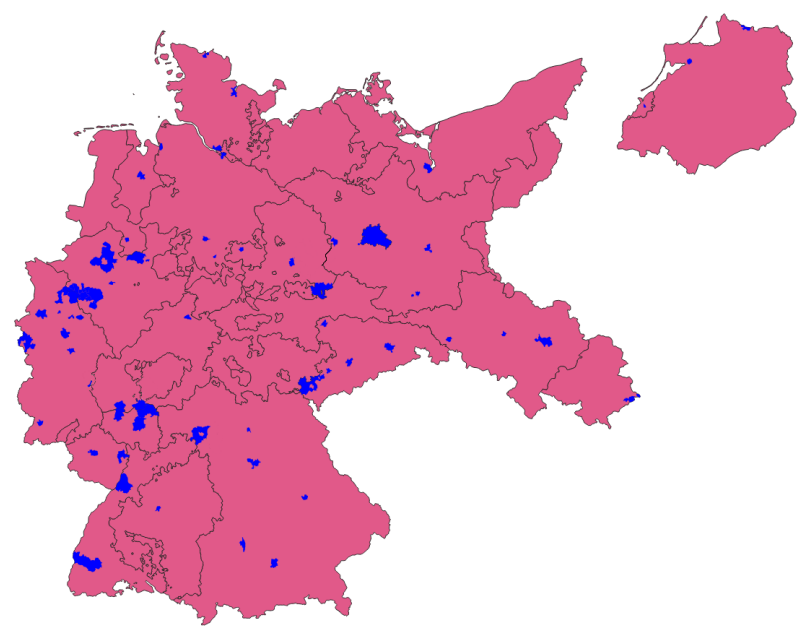

(a) Towns in sample

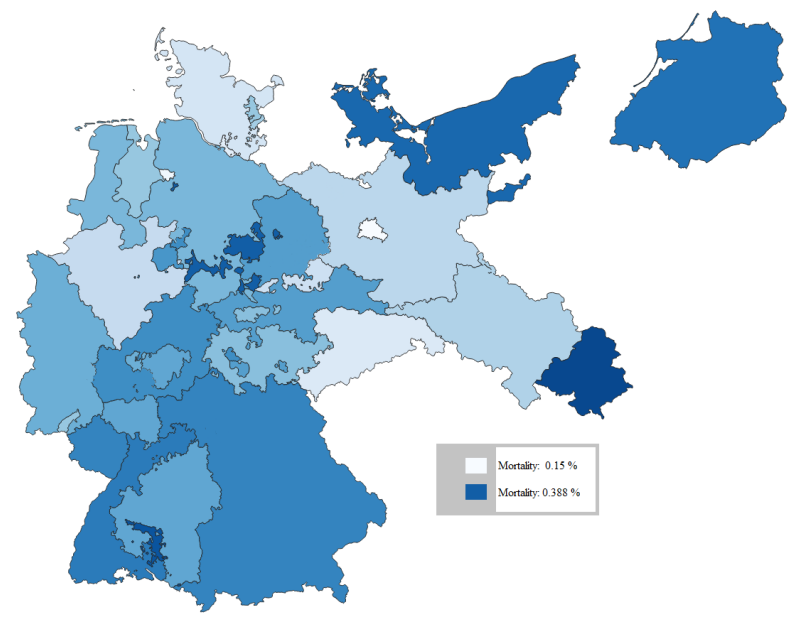

(b) Regional Influenza Mortality 1918

Figure A.1: Panel A depicts the towns in the sample, in blue, on a Map of Germany. Town boundaries are community/county boundaries of 1922. Some towns are much smaller, based on county boundaries, than others. County boundaries are not based on population. Panel B depicts influenza mortality rates per "region" in Germany in 1918. Darker areas experience larger influenza mortality. Data for the Mecklenburg Schwerin area as well as the remnants of Posen and West-Prussia is not available. Maps are based on data from the MPIDR (Max Planck Institute for Demographic Research) and CGG (Chair for Geodesy and Geoinformatics, University of Rostock) 2011. 


\section{B Additional/Alternate Specifications}

The following are alternate specifications and extensions to the main specifications presented in the paper above.

Table A.2 depicts the baseline regression of influenza mortality on the share of National Socialist party votes, but makes use of the year 1933 instead of 1932 and 1933. The results are confirmed despite a small sample size. Similarly, Table A.3 lumps the years 1928 and 1930 into the sample. One can see that the results hold for the entire period during which the National Socialist party existed as a serious political contender, though they are strongest in the final years.

Table A.4 combines influenza and pneumonia deaths to determine if the effect is driven by a misreporting of influenza as pneumonia in some regions. This follows from the fact that (i) the diseases sometimes manifested very similar symptoms and (ii) some regions with worse medical care may have systematically categorized some diseases incorrectly. In fact, a small though significant increase in pneumonia cases could be observed in 1918. This may be the result of incorrect categorization ${ }^{1}$ or due to compounding infections. As can be seen, however, the results are confirmed when combining both types of death. It is therefore unlikely that false classifications are driving the observed results. Although tuberculosis deaths are themselves not a driver of influenza, results are robust to combining all three causes of death.

\footnotetext{
${ }^{1}$ See, for instance Pettit (1976) for a discussion of the difficulties in identifying influenza in early 1918 and how even the poet Robert Frost, who it now seems suffered from Influenza, was originally believed/assumed by contemporaries to have contracted pneumonia or tuberculosis. See also https://www.nih.gov/news-events/news-releases/bacterial-pneumoniacaused-most-deaths-1918-influenza-pandemic for a discussion of pneumonia related illnesses compounding the effects of influenza.
} 
Table A.2: Single year

\begin{tabular}{lccccc}
\hline \hline & $(1)$ & $(2)$ & $(3)$ & $(4)$ & $(5)$ \\
& NS Vote '33 & NS Vote '33 & NS Vote '33 & NS Vote '33 & NS Vote '33 \\
\hline Influenza mortality 1918 & $66.98^{* * *}$ & $63.75^{* * *}$ & $63.78^{* * *}$ & $47.01^{* *}$ & $48.56^{* *}$ \\
& {$[15.47]$} & {$[17.08]$} & {$[17.79]$} & {$[19.39]$} & {$[18.32]$} \\
Spend. per inh. & & & & & \\
& & 0.00147 & 0.00174 & -0.0183 & \\
& & {$[0.0304]$} & {$[0.0346]$} & {$[0.0397]$} & \\
Change in per capita spend. 1930-1932 & & & & & -3.513 \\
& & & & & Yes \\
\hline Basic Controls & Yes & Yes & Yes & Yes & Yes \\
Wage Controls & No & No & Yes & Yes & Yes \\
Employment Controls & No & No & No & Yes & Yes \\
Hyperinflation Controls & No & Yes & Yes & Yes & 0.718 \\
$\mathrm{R}^{2}$ & 0.671 & 0.668 & 0.668 & 0.717 & 72 \\
$\mathrm{~N}$ & 77 & 74 & 74 & 73 & 73 \\
\hline \hline
\end{tabular}

Note: This table shows the coefficients for variants of equation:

$$
\text { ExtremistVote }_{c, r, 1933}=\beta_{0}+\beta_{l} \text { InfluenzaMortality }_{r, 1918}+\beta_{2} \text { CitySpending }_{c, 1933}+\mathbf{X}_{c}+\theta_{t}+\xi_{r}+\epsilon_{c, t},
$$

Extremist Vote tracks the share of votes obtained by the national socialist party in 1933 . The coefficients of interest are $\beta_{1}$ which show the impact of the influenza mortality rate in 1918. The specification includes city-tier and year fixed effects. Basic controls include share of influenza deaths that were female, town size, change in regional population between 1910 and 1918, change in city level population between 1912 and 1930, percentage of the population that was Catholic or Jewish in 1925 as well as the vote share of right wing parties in 1912. Wage controls are city-level wages for metal workers in 1930 and 1932. Employment controls are regional unemployment in 1930 and the change in unemployment to year-end 1931. Hyperinflation controls reflect the highest level of inflation, relative to a pre-war level of $1913 / 14$, a city experienced in 1923. Robust standard errors are clustered at the Region*Year level and in parentheses; *,**, and *** indicate significance at the $10 \%, 5 \%$, and $1 \%$ level, respectively. 
Table A.3: Multiple years

\begin{tabular}{|c|c|c|c|c|c|}
\hline & $\begin{array}{c}(1) \\
\text { NS vote share }\end{array}$ & $\begin{array}{c}(2) \\
\text { NS vote share }\end{array}$ & $\begin{array}{c}(3) \\
\text { NS vote share }\end{array}$ & $\begin{array}{c}(4) \\
\text { NS vote share }\end{array}$ & $\begin{array}{c}(5) \\
\text { NS vote share }\end{array}$ \\
\hline Influenza mortality 1918 & $45.39^{* * * *}$ & $43.67^{* * *}$ & $43.69^{* * *}$ & $40.12^{* * *}$ & $41.57^{* * *}$ \\
\hline Spend. per inh. & & $\begin{array}{c}0.000214 \\
{[0.0190]}\end{array}$ & $\begin{array}{c}-0.00332 \\
{[0.0176]}\end{array}$ & $\begin{array}{c}-0.00500 \\
{[0.0180]}\end{array}$ & \\
\hline Change in per capita spend. $1930-1932$ & & & & & $\begin{array}{c}-8.219^{* *} \\
{[3.269]}\end{array}$ \\
\hline Basic Controls & Yes & Yes & Yes & Yes & Yes \\
\hline Wage Controls & No & No & Yes & Yes & Yes \\
\hline Employment Controls & No & No & No & Yes & Yes \\
\hline Hyperinflation Controls & No & Yes & Yes & Yes & Yes \\
\hline$R^{2}$ & 0.816 & 0.813 & 0.814 & 0.822 & 0.827 \\
\hline $\mathrm{N}$ & 234 & 225 & 225 & 222 & 220 \\
\hline
\end{tabular}

Note: This table shows the coefficients for variants of equation:

$$
\text { ExtremistVote }_{c, r, t}=\beta_{0}+\beta_{l} \text { InfluenzaMortality }, 1918+\beta_{2} \text { CitySpending }_{c, 1933}+\mathbf{X}_{c}+\theta_{t}+\xi_{r}+\epsilon_{c, t}
$$

Extremist Vote tracks the share of votes obtained by the national socialist party in 1928, 1930, 1932, and 1933. The coefficients of interest are $\beta_{1}$ which show the impact of the influenza mortality rate in 1918. The specification includes city-tier and year fixed effects. Basic controls include share of influenza deaths that were female, town size, change in regional population between 1910 and 1918, change in city level population between 1912 and 1930, percentage of the population that was Catholic or Jewish in 1925 as well as the vote share of right wing parties in 1912. Wage controls are city-level wages for metal workers in 1930 and 1932. Employment controls are regional unemployment in 1930 and the change in unemployment to year-end 1931. Hyperinflation controls reflect the highest level of inflation, relative to a pre-war level of 1913/14, a city experienced in 1923. Robust standard errors are clustered at the Region*Year level and in parentheses; ${ }^{*}, * *$, and ${ }^{* * *}$ indicate significance at the $10 \%, 5 \%$, and $1 \%$ level, respectively. 
Table A.4: Influenza, Pneumonia, and Tuberculosis combined

\begin{tabular}{lcccc}
\hline \hline & $(1)$ & $(2)$ & $(3)$ & $(4)$ \\
& NS Vote & NS Vote & NS vote '30-33 & NS Vote \\
\hline Inf. and Pneu. mortality 1918 & $26.02^{* *}$ & $23.26^{* *}$ & $28.42^{* * *}$ & \\
& {$[12.29]$} & {$[10.63]$} & {$[9.064]$} & \\
Pneu., Tub., and Infl. mortality & & & & $20.46^{* *}$ \\
& & & & {$[7.864]$} \\
\hline \hline \multirow{2}{*}{ Basic Controls } & No & Yes & Yes & Yes \\
Wage Controls & No & Yes & Yes & Yes \\
Unemployment Controls & No & Yes & Yes & Yes \\
Hyperinflation Controls & No & Yes & Yes & Yes \\
$\mathrm{R}^{2}$ & 0.756 & 0.799 & 0.830 & 0.800 \\
$\mathrm{~N}$ & 151 & 143 & 216 & 143 \\
\hline \hline
\end{tabular}

Note: This table shows the coefficients for variants of equation:

$$
\text { ExtremistVote }_{c, r, t}=\beta_{0}+\beta_{l} \text { CmbinedMortality }_{r, 1918}+\beta_{2} \text { CitySpending }_{c, 1933}+\mathbf{X}_{c}+\theta_{t}+\xi_{r}+\epsilon_{c, t},
$$

Extremist Vote tracks the share of votes obtained by the national socialist party in 1930, 1932, and 1933, or 1932 and 1933 . The coefficients of interest are $\beta_{1}$ which show the impact of the influenza and pneumonia mortality rate in 1918 (or the combined influenza, pneumonia and tuberculosis mortality). The specification includes city-tier and year fixed effects. Basic controls include share of influenza deaths that were female, town size, change in regional population between 1910 and 1918, change in city level population between 1912 and 1930 , percentage of the population that was Catholic or Jewish in 1925 as well as the vote share of right wing parties in 1912. Wage controls are city-level wages for metal workers in 1930 and 1932. Employment controls are regional unemployment in 1930 and the change in unemployment to year-end 1931. Hyperinflation controls reflect the highest level of inflation, relative to a pre-war level of 1913/14, a city experienced in 1923. Robust standard errors are clustered at the Region*Year level and in parentheses; ${ }^{*}, * *$, and ${ }^{* * *}$ indicate significance at the $10 \%, 5 \%$, and $1 \%$ level, respectively. 


\section{Austerity and Extremism}

As has been established, for instance by Galofré-Vilà et al. (2019), extremism is driven, in part, by austerity. Using the data on city spending and city election results employed in this paper, one can observe a relationship between spending on inhabitants and the electoral success of extremists. Lower per-capita spending is associated with a higher National Socialist vote share. Moreover, the contraction in spending, from its highest points around 1930 or 1929 to its lows in 1932, following the banking system collapse, also exert a significant impact. The patterns are displayed in Figure A.2. Lower relative spending or a contraction in spending and the associated disappearance of amenities may fuel anti-establishment resentment. For this reason most regressions in the paper above control for city-level expenditure as well as unemployment and city-level wages when analyzing the impact of influenza on extremist voting.

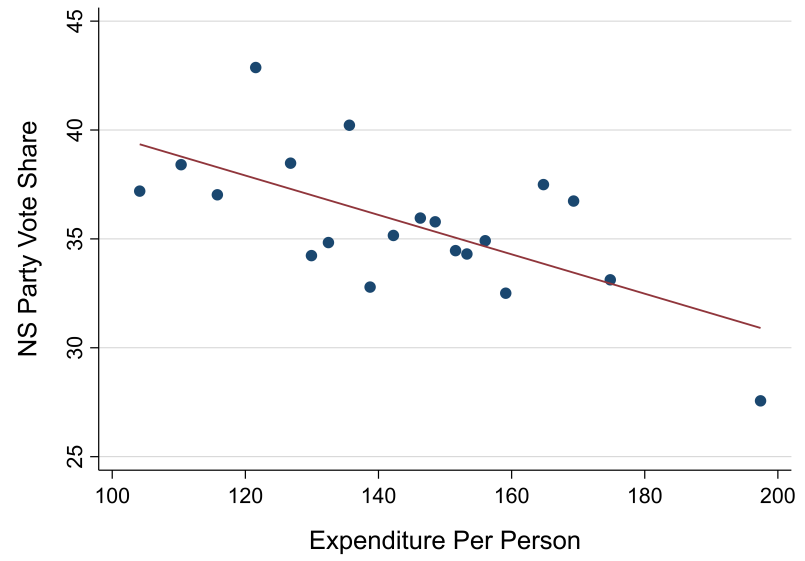

(a) Nat. Soc. vote share 1933 vs. city spending in 1932

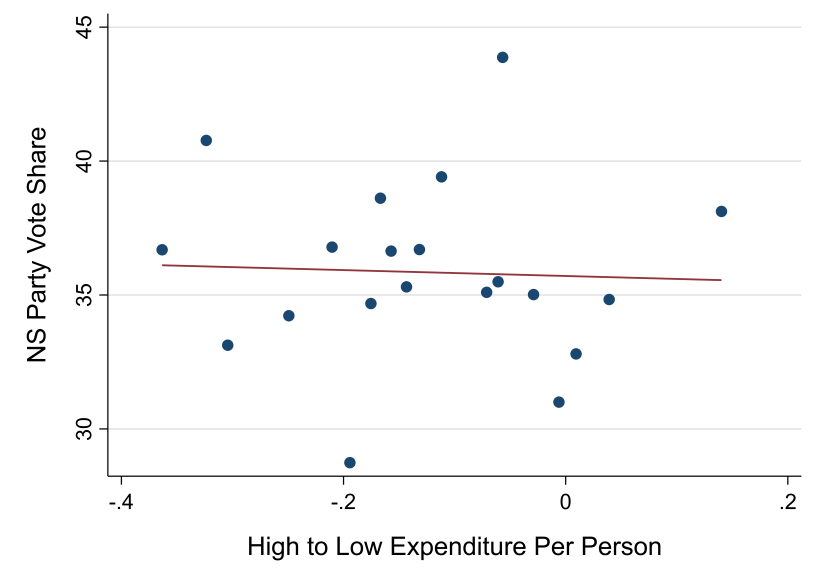

(b) Nat. Soc. vote share 1933 vs. change in city spending in 1929 to 1932

Figure A.2: Nat. Soc. Vote Share v. City Spending per Capita Per-capita spending of cities in 1932 in panel (a) or change in city spending between its high point in 1929/30 and $1932 \mathrm{in} \mathrm{panel} \mathrm{(b)} \mathrm{relative} \mathrm{to} \mathrm{the} \mathrm{share} \mathrm{of} \mathrm{the} \mathrm{vote} \mathrm{obtained} \mathrm{by}$ the National socialist party in 1933. The scatterplot represents residuals; controls include city-tier, year, town-size, percent of local population that is Jewish and Catholic, share of population that is unemployed. 